\title{
NOTAS PARA O ESTUDO DA IMPRENSA NA REGENCIA: PERNAMBUCO E BAHIA (1829-1836)
}

Silvia Brito Fonseca ${ }^{1 ; 2}$

\section{Resumo}

Este artigo percorre a imprensa pernambucana e baiana entre 1829 e 1836 no intuito de reconstruir a rede estabelecida entre redatores de jornais, membros das sociedades políticas e lideranças das sublevações nas ruas de Recife e Salvador no início do período regencial. O texto sugere que a imprensa se apresenta como principal guardiã das memórias locais, além de se constituir como principal fonte para a reflexão acerca das relações entre os poderes locais e o governo central.

\section{Palavras-chave}

Imprensa - federalismo - Pernambuco - Bahia - Regência.

\section{NOTES FOR THE STUDY OF THE PRESS IN THE REGENCY: PERNAMBUCO AND BAHIA (1829-1836)}

\section{Abstract}

This article intends to study the press in Pernambuco and Bahia from 1829 to 1836 in order to examine journalists, members of political associations and leaders of rebellions in Recife and Salvador in the first years of the period of Regencies. It argues that the press represents the local history, besides is the main source to understand the conflicts between the local authorities and the central government.

\section{Keywords}

Press - federalism - Pernambuco - Bahia - Regency.

\footnotetext{
${ }^{1}$ Universidade Federal do Estado do Rio de Janeiro (UNIRIO). Rio de Janeiro - Rio de Janeiro - Brasil.
}

${ }^{2}$ Doutora em História Social pela Universidade Federal do Rio de Janeiro (2004). Autora do livro A ideia de república no império

do Brasil: Rio de Janeiro e Pernambuco (1824-1834). 
Este artigo reconstitui a atividade política em Pernambuco e na Bahia em prol do federalismo - as sublevações armadas assim como o movimento associativo - à luz dos periódicos que circularam nas respectivas províncias entre 1829 e 1836.

Parece haver certo consenso quanto a pouca atenção dada pela historiografia ao período das regências. Nos últimos 40 anos, algumas pesquisas desenvolvidas no âmbito dos cursos de pósgraduação relativizaram tal percepção, sobretudo no campo da história política ${ }^{3}$. No entanto, se considerarmos a importância da revolução do 7 de abril, atestada sobretudo pela imprensa da Corte e das províncias, assim como o sentimento de ruptura e transitoriedade manifestado por aqueles que vivenciaram a década de 1830, observa-se que a produção acadêmica ainda é discreta. Por esse motivo, lembra com razão Marcello Basile que, dentre as principais obras de referência para o estudo do período, figuram os nove volumes de biografias escritas por Octavio Tarquínio de Sousa ${ }^{4}$ entre 1940 e 1950 e editadas entre 1957 e 1958, os textos de Moreira de Azevedo impressos no final do século XIX, assim como a célebre síntese de Paulo Pereira de Castro, A experiência republicana, inscrita na coleção História geral da civilização brasileira publicada nos anos $1970^{5}$.

Ainda que não seja a intenção deste artigo analisar as razões de tal desinteresse, talvez seja plausível a hipótese de que a memória construída no Segundo Reinado a respeito dos anos que se seguem à abdicação de d. Pedro I tenha contribuído para elidir a pluralidade dos projetos políticos que se apresentavam naquele contexto.

Ainda hoje os manuais escolares relacionam o período regencial ao caos e ao tão propalado separatismo das províncias que constituíam o Império do Brasil, perigos que teriam sido devidamente atalhados pelo Regresso conservador. Quando este não é mencionado, segue a antecipação da maioridade de d. Pedro II, tema imediatamente tratado após a exposição das calamidades promovidas pelas chamadas grandes revoltas, decorridas a partir de 1835 no Rio Grande do Sul, na Bahia, no Pará e no Maranhão. A despeito da ênfase na longevidade de tais sublevações, na extensão das áreas conflagradas e no grande número de mortos vitimados pelas tropas imperiais, via de regra não se observa qualquer reflexão acerca das motivações daqueles que delas tomaram parte, bem como suas particularidades locais.

Como é conhecido, no cerne do processo de consolidação do Estado imperial se implementa o projeto de pensar a história do Brasil. Nesse mesmo movimento ganha dimensão a centralidade conferida ao território. Assim, no cruzamento entre tempo e espaço, história e geografia, emerge a sacralização do território, visto no âmbito do Instituto Histórico e Geográfico Brasileiro como principal herança da colonização portuguesa. Nos termos da Constituição de 1824, a divisão do Império em "províncias" remetia à conquista e à opressão, uma vez que sua origem latina significa "vencer ao longe". A etimologia do vocábulo não escapou ao redator do periódico da Sociedade Federal de Pernambuco em 1832. Nas páginas do jornal O Federalista, assim como na folha Bussola da Liberdade, João Barboza Cordeiro salientava a impropriedade que julgava ter a nomenclatura administrativa no Brasil, sugerindo à câmara eletiva que mudasse "o nome odioso de Província, substituindo-lhe o de Cantões ou Estados"6.

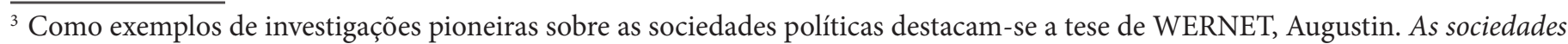
políticas da província de São Paulo na primeira metade do período regencial. Tese (Doutorado), USP, 1975. 2 vol.; bem como a dissertação de mestrado de GUIMARÃES, Lúcia Maria Paschoal. Em nome da ordem e da moderação: a trajetória da Sociedade Defensora da Liberdade e da Independência Nacional do Rio de Janeiro (1831-1835). Dissertação (Mestrado), UFRJ, 1990. Cumpre citar também alguns trabalhos mais recentes que examinam as facções políticas na Corte como o de MOREL, Marco. As transformações dos espaços públicos: imprensa, atores políticos e sociabilidades na cidade imperial (1820-1840). São Paulo: Hucitec, 2005; BASILE, Marcelo O. N. de Campos. O império em construção: projetos de Brasil e ação política na Corte regencial. Tese (Doutorado), UFRJ, Rio de Janeiro, 2004; SILVA, Wlamir Jose da. Liberais e povo: a construção da hegemonia liberal moderada na província das Minas Gerais (1830-1834). São Paulo: Hucitec, 2009; LYRA, Maria de Lourdes Viana. O império em construção: Primeiro reinado e regências. São Paulo: Atual, 2000; MOREL, Marco. O período das regências (1831-1840). Rio de Janeiro: Jorge Zahar, 2003; LIMA, Ivana Stolze. Cores, marcas e falas: sentidos da mestiçagem no Império do Brasil. Rio de Janeiro: Arquivo Nacional, 2003. cap. 1; FONSECA, Silvia C. P. de Brito. A ideia de República no Império do Brasil: Rio de Janeiro e Pernambuco (1824-1834). Jundiaí: Paco Editorial, 2016.

${ }^{4}$ SOUSA, Otávio Tarquínio de. História dos fundadores do Império do Brasil. Rio de Janeiro: José Olympio Editora, 1957. Como se sabe, o volume X é composto do índice geral e de um apêndice que trata das organizações ministeriais do Império.

${ }^{5}$ BASILE, Marcelo O. N. de Campos. O laboratório da nação: a era regencial (1831-1840). In: GRINBERG, Keila; SALLES, Ricardo (org.). O Brasil imperial. Rio de Janeiro: Civilização Brasileira, 2009. vol. 2, p. 56.
}

${ }^{6}$ O Federalista n. 4, 28 de janeiro de 1832. 
Entendimento diverso da ideia de nação inspirou o texto constitucional. Assim sendo, a monarquia unitária privava as partes constitutivas do Império de qualquer identidade política ou cultura histórica local. Tal princípio adquire maior clareza na formulação de José Antônio Pimenta Bueno, marquês de São Vicente, em sua célebre análise à Constituição de 1824, publicada em 1857: "Por isso mesmo que o império é um e único, que ele não é dividido em províncias senão no sentido e fim de distribuir convenientemente os órgãos da administração"7.

Do ponto de vista semântico, a própria ideia de império inscreve em seu significado o domínio territorial. A esse respeito é preciso lembrar a reflexão de Ilmar Rohloff de Mattos, segundo a qual a longa e tortuosa associação entre Império do Brasil e nação brasileira, propiciada pela construção do Estado imperial, implicou na elisão das identidades geradas no período colonial, através "da difusão dos valores, signos e símbolos imperiais, da elaboração de uma língua, uma literatura e uma história nacionais". Conforme a interpretação do eminente historiador, nessa particular expansão, uma "expansão para dentro", residiria o elemento que singularizava o Império do Brasil. "Impossibilitado de expandir suas fronteiras, o Estado imperial era obrigado a empreender uma expansão diferente: uma expansão para dentro. E aí reside o traço mais significativo na construção de uma unidade"8. Todavia, eram outras as expectativas geradas pelas notícias que chegaram a Pernambuco e à Bahia no início de maio de 1831, conforme manifestaram os jornais Diário de Pernambuco e Espelho das Brazileiras.

TEMOS a satisfação de dar a saber aos nossos caros Concidadãos os felizes sucessos da Capital do Império: triunfou a Opinião Pública! Parabéns Pernambucanos!

Usando do Direito que a Constituição me Concede, Declaro que Hei mui voluntariamente Abdicado na Pessoa de Meu Muito Amado e Prezado Filho, o Senhor D Pedro de Alcântara. Boa vista sete de abril de mil oitocentos e trinta um, décimo da Independência e do Império. Pedro.

Copiado do Baiano n. 41, 23 de abril $1831^{9}$.

No número seguinte, o Diário de Pernambuco imprimiu uma Proclamação assinada pelo presidente e pelo conselho da província.

Pernambucanos

Notícias Extraordinárias acabam de chegar a esta Cidade trazidas da Bahia por uma Embarcação Inglesa, que afirma ter se espalhado por aquela Cidade que o Imperador abdicou à Coroa deste Império em seu Augusto Filho; que já se elegera uma Regência Provisória, até que a Assembleia Geral haja de nomear a permanente; que o Imperador abdicante partira para a Inglaterra e que tudo isto foi feito sem perturbação do sossego público. Estas notícias não são oficiais; mas como por sua magnitude podem agitar os Espíritos, causando-lhes impressões diversas, conforme o modo de pensar de cada um, o Presidente e Conselho vos exorta para que permaneçais tranquilos, e suspendais, até que se recebam notícias oficiais, qualquer juízo a tal respeito.

Confiai no Governo da Província. Ele se empenha com o maior desvelo em manter vossa tranquilidade e vossa dignidade.

Mostrai ao Brasil e ao Mundo inteiro que vossa tranquilidade somente será alterada pela menor ameaça da vossa liberdade.

Viva a Nação Brasileira. Viva a Liberdade Legal. Viva o Governo, que nos marcou a Constituição jurada. Palácio do Governo de Pernambuco, 4 de maio de 1831.

Joaquim José Pinheiro de Vasconcellos $=$ Francisco de Paula Cavalcante de Albuquerque $=$ Bernardo Luiz Ferreira $=$ Gervázio Pires Ferreira $=$ Manoel Zeferino dos Santos $=$ Monoel $($ sic) Ignácio de Carvalho $=$ Thomaz Antonio

Maciel Monteiro ${ }^{10}$.

\footnotetext{
${ }_{7}$ BUENO, Jose Antônio Pimenta. Direito público brasileiro e análise da Constituição do Império. Brasília: Senado Federal, 1978. p. 22. Ver a arguta análise de MATTOS, Ilmar Rohloff de. O tempo saquarema. São Paulo: Hucitec; Brasília: INL, 1987. p. 83-85.

${ }^{8}$ MATTOS, Ilmar Rohloff de. Construtores e herdeiros. A trama dos interesses na construção da unidade política. In: JANCSÓ, István (org.). Independência: história e historiografia. São Paulo: Hucitec: Fapesp, 2005. p. 300.

${ }_{9}$ Suplemento ao Diário de Pernambuco, n. 95, 4 de maio de 1831; Espelho das Brazileiras, n. 28, 6 de maio de 1831.

10 Diário de Pernambuco n. 96, 5 de maio de 1831
} 


\section{Tempo de ruptura e expectativa}

É pois chegado o tempo de perguntarmos ao Brasil o que éramos, o que somos e o que devemos ser ${ }^{11}$.

A revolução do 7 de abril engendrou um momento singular no qual os sentimentos de ruptura e transitoriedade propiciaram, além da avaliação negativa do passado recente, a possibilidade de moldar o futuro por meio da reforma constitucional. Como se sabe, o artigo 174 da Constituição de 1824 previa a alteração de qualquer dispositivo no prazo de quatro anos, caso tal proposta partisse da câmara eletiva e contasse com o apoio de no mínimo um terço dos deputados. Perfeitamente cientes dessa brecha na legislação, os redatores dos jornais ampliaram consideravelmente o debate político a partir de 1829, sobretudo no que concerne às relações entre o governo central e as províncias. No entanto, nesse contexto há outros fatores correlatos que resultam da conformação de uma esfera pública política decorrente da multiplicação dos espaços de convivência cotidiana que se traduziam em diferentes formas de participação política.

Em primeiro lugar, é importante lembrar a aprovação de um conjunto de medidas pela Câmara dos Deputados, reaberta em 1826, que tendia a fixar e a restringir a esfera de ação política do Executivo, atualizando a legislação aos "novos tempos". Convém citar a extinção dos tribunais herdados do Reino Unido - o Desembargo do Paço e a Casa de Suplicação - e a criação do Supremo Tribunal de Justiça; a instituição do Juizado de Paz; bem como a reforma das câmaras municipais. Decerto que tais iniciativas denotavam o declínio das formas corporativas de representação, mas também visavam a autonomização de diversas instâncias do governo em relação ao imperador, além de promover a disjunção entre os ofícios administrativos e judiciais ${ }^{12}$.

Vale realçar da mesma forma o reconhecimento do direito de resistência à ação ilegal das autoridades, além da participação popular no serviço de júri, consignado pelo Código de Processo Criminal de $1832^{13}$. Conforme suas disposições são conferidas funções judiciais e policiais aos juízes de paz. Sufragados diretamente pelos eleitores da paróquia, suas atribuições abrangiam desde a justiça primária das conciliações, o julgamento de pequenas contravenções, até a intervenção direta nos movimentos de rua. A ação do Juizado de Paz foi notória nas manifestações populares que se sucederam na Corte ao longo de 1831, como ocorreu nos distúrbios do teatro São Pedro em 28 de setembro, quando coube a Saturnino de Souza e Oliveira, juiz de paz da freguesia do Sacramento, exclusividade na formação de culpa e pronunciamento de indiciados. O Código de Processo instituiu igualmente o júri como tribunal criminal, tornando seu exercício acessível a todos os cidadãos considerados aptos a serem eleitores, nos termos da Constituição de 1824, além de eliminar foros privilegiados, com exceção da família imperial e do Legislativo.

Em segundo lugar, ao lado do aspecto formal, é preciso relevar o intenso envolvimento da população nos protestos nas ruas, anteriores e posteriores à abdicação em $1831^{14}$. O terceiro elemento

\footnotetext{
$\overline{11}$ Nova Luz Brasileira n. 143, 27 de maio de 1831.

${ }^{12}$ LOPES, José Reinaldo de Lima. Iluminismo e jusnaturalismo no ideário dos juristas da primeira metade do século XIX. In: JANCSÓ, István. Brasil: formação do Estado e da nação. São Paulo: Hucitec: Ed. Unijuí: Fapesp, 2003. SOUZA, Iara Lis Franco Schiavinatto Carvalho. Pátria coroada: o Brasil como corpo político autônomo (1780-1831). São Paulo: Fundação Editora da Unesp, 1999. p. 340, 341.
}

13 CARVALHO, José Murilo de. Cidadania: tipos e percursos. In: Estudos Históricos. Fundação Getúlio Vargas, n. 18, 1996. p. 344.

${ }^{14}$ Entre os movimentos anteriores à Abdicação, incluem-se, como se sabe, os conflitos entre portugueses e brasileiros ocorridos no Rio de Janeiro nos dias 13, 14 e 15 de março de 1831, denominado pela historiografia de Noite das Garrafadas. Sobre este episódio, ver: Hum Verdadeiro Constitucional (pseud.), Defesa ou Fiel e verdadeira exposição dos acontecimentos que tiverão lugar no Rio de Janeiro, por occasião da chegada de SS. MM. II nas noites de 11 a 15 de março, que ao respeitável corpo do commercio, offerece um verdadeiro constitucional. Rio de Janeiro: Typographia do Diário, 1831; os tumultos promovidos no aniversário da Constituição, em 25 de março; bem como a rebelião, rapidamente abafada, dos criados do paço no dia 29 do mesmo mês. Sobre os antecedentes da Abdicação, ver BASILE, Marcello. O Império em construção: projetos de Brasil e ação política na Corte regencial. Rio de Janeiro: Tese (Doutorado), UFRJ, 2004. Introdução. Ver também RIBEIRO, Gladys Sabina. A liberdade em construção. Rio de Janeiro: Relume Dumará: Faperj, 2002. Introdução. Ainda em 26 de março, o ministro da Justiça, por meio da lei $\mathrm{n}^{\circ} 46$ "manda tomar todas as cautelas convenientes para prevenir predisposições de partidos exaltados”. Coleção de Leis do Império do Brasil. Rio de Janeiro: Typographia Nacional, 1831. 
que conferiu uma dinâmica mais participativa à vida política no período regencial diz respeito à ampliação da organização das sociedades políticas e civis ${ }^{15}$, o que se inscreve no processo apontado por Habermas em relação à passagem das sociedades secretas para as associações livres ${ }^{16}$.

Direta ou indiretamente associadas às diferentes correntes políticas, se destacam a Sociedade Defensora da Liberdade e Independência Nacional, criada em março de 1831 em São Paulo e em maio do mesmo ano no Rio de Janeiro, vinculada ao grupo liberal moderado a partir do final de 1831; a Sociedade Federal, dedicada à campanha em favor do federalismo, fundada em Pernambuco em 16 de outubro, na Bahia no dia 30 de novembro e na Corte em dezembro de 1831; e a Sociedade Conservadora da Constituição Jurada no Império do Brasil, estabelecida em janeiro de 1832 e substituída em 1833 pela Sociedade Militar, reunindo caramurus e restauradores ${ }^{17}$. O Diário de Pernambuco anunciou em fevereiro de 1832 a instalação em São Paulo da Sociedade Auxiliadora da Federação ${ }^{18}$. Augustin Wernet, no entanto, datou a constituição da Sociedade Federal em São Paulo em dezembro de 1831. Possivelmente se trata da mesma agremiação ${ }^{19}$.

Além das sociedades políticas, é possível encontrar alusões a outros clubes, sobre os quais pouco se escreveu, como o chamado Clube da rua dos Pescadores, localizado na residência e livraria de Evaristo da Veiga, na qual se reuniam políticos da facção moderada, como Diogo Antônio Feijó, Francisco Sales Torres Homem e Rodrigues Torres. Outro clube que teria tido grande influência no 7 de abril seria o Clube dos Amigos Unidos, instituído "com fórmulas maçônicas", que contava, segundo Tarquínio de Sousa, com a participação de Teófilo Otoni como secretário. Ainda de acordo com o autor, o clube pretenderia “não apenas uma república provisória, mas o 'próprio governo do povo por si mesmo', (...) jurando sobre o sangue dos Canecas e dos Ratcliffs" 20 .

O quarto elemento sinalizador da conformação de um espaço público político é a proliferação de periódicos doutrinários na Regência. A rigor, a imprensa não apenas articulou as demais instâncias - o debate na câmara eletiva, a organização das sociedades políticas e os movimentos de protesto nas ruas -, como também fabricou a própria ideia de opinião pública, conferindo-lhe autonomia. Nessa circunstância, os jornais julgavam desempenhar um duplo papel: ao mesmo tempo formar e espelhar a opinião pública ${ }^{21}$. A esse respeito, é curioso acompanhar a "seção de correspondências" dos leitores, inserida em inúmeras folhas e identificada como um "espaço possível de cidadania". Por meio da publicação de tais cartas, os jornais pretendiam construir um espaço público de debates, confronto de ideias, denúncias e reivindicações, a despeito da provável participação dos próprios redatores, por meio de pseudônimos ${ }^{22}$.

\footnotetext{
$\overline{15}$ Ainda são poucos os estudos sobre as sociedades políticas, com exceção, em alguma medida, da Sociedade Defensora. Sobre a Sociedade Federal de Pernambuco ver FONSECA, Silvia C. P. de Brito. A ideia de República no Império do Brasil... Op. Cit., 2016. cap. 6. Sobre essas organizações em São Paulo ver WERNET, Augustin. Sociedades políticas (1831-1832). São Paulo: Cultrix, 1978. Ver também GUIMARÃES, Lúcia Maria Paschoal. Em nome da ordem e da moderação... Op. Cit., 1990; e BASILE, Marcello. O Império em construção... Op. Cit., 2004.

${ }^{16}$ HABERMAS, Jürgen. Mudança estrutural na esfera pública. Rio de Janeiro: Tempo Brasileiro, 1984. p. 51 e 52. KOSELLECK, Reinhart. Crítica e crise: uma contribuição à patogênese do mundo burguês. Rio de Janeiro: Eduerj; Contraponto, 1999. capítulo segundo.

${ }^{17}$ Sobre a Sociedade Militar e a ação política dos caramurus no Rio de Janeiro ver BASILE, Marcello. O Império em construção... Op. Cit., 2004. Ver também MOREL, Marco. Restaurar, fracionar e regenerar a nação: o Partido Caramuru nos anos 1830. In: JANCSÓ, István (org.). Brasil: formação do Estado e da nação. São Paulo: Hucitec; Ed. Unijuí; Fapesp, 2003.

18 Diário de Pernambuco, n. 304, 6 de fevereiro de 1832

19 WERNET, Augustin. Sociedades políticas... Op. Cit., 1975. vol. 1, p. 111.

${ }^{20}$ João Guilherme Ratcliff, sempre lembrado pela imprensa exaltada ao lado de frei Caneca, foi enforcado no Rio de Janeiro por sua participação na Confederação do Equador. SOUSA, Otávio Tarquínio de. História dos fundadores do Império do Brasil... Op. Cit., 1957. vol. IX, p. 271. Moreira de Azevedo também alude ao Clube dos Amigos Unidos, possivelmente criado na Corte em 1830, sem atribuir-lhe, no entanto, qualquer propensão às ideias republicanas, embora Cipriano Barata tivesse sido eleito presidente honorário da associação. De acordo com seu depoimento, a sociedade secreta teria contado com a participação de Antônio José do Amaral, José Augusto Cesar de Menezes, João Pedro Maynard, dr. Joaquim José da Silva e Teófilo Ottoni, assegurando este último o papel decisivo da associação na "revolução do 7 de abril". AZEVEDO, Manuel Duarte Moreira de. Sociedades fundadas no Brasyl desde os tempos coloniais até o começo do actual Reinado. Revista Trimensal do Instituto Histórico, Geographico e Ethnographico do Brasil. Rio de Janeiro: Typ. de Laemmert, 1885. tomo XLVIII, parte 2, p. 293.

${ }^{21}$ Sobre a gênese da noção de opinião pública ver MOREL, Marco. As transformações dos espaços públicos: imprensa, atores políticos e sociabilidades na cidade imperial (1820-1840). São Paulo: Hucitec, 2005. cap. 6.

${ }^{22}$ FÜRSTENAU, Vera. Jornais e leitores: uma polêmica apaixonada na cidade do Rio de Janeiro (1831-1837). Dissertação (Mestrado), UFRJ, Rio de Janeiro, 1994.
} 
É de notar também que, à época, para além do testemunho dos viajantes, dos relatos dos emissários e da correspondência oficial ou particular era através da imprensa que se tomava conhecimento do que se passava à distância. Os jornais dispunham, senão do monopólio da narrativa e da construção dos "fatos", da possibilidade concreta de reelaborar a ideia de nação, enquanto conjunto de províncias que constituíam o Império do Brasil. Ao se percorrer as páginas dos jornais também chamam a atenção as onipresentes transcrições de outros periódicos, as polêmicas travadas entre redatores, bem como as referências às sociedades políticas de diversas províncias. Desse modo, tais agremiações e a imprensa, ao menos no Rio de Janeiro, em Pernambuco e na Bahia, constituíam uma rede que agregava redatores de jornais e sócios com formação heterogênea, mas em permanente contato. A folha pernambucana Bandeira de Retalhos é um bom exemplo, mas não o único, da afinidade de propósitos entre jornais de diferentes e distantes províncias. Esse periódico consagrou todas as suas edições, ao menos as que restaram na Biblioteca Nacional, à oposição a Diogo Feijó, então ministro da Justiça, bem como à descrição dos sucessos decorridos no Rio de Janeiro, notadamente os conflitos nas ruas e as perseguições movidas contra redatores fluminenses e pernambucanos.

Por acharmos útil aos Brasileiros a leitura dos Seguintes artigos do Exaltado, os transcrevemos na Bandeira de Retalhos, e muito recomendamos o Segundo por ser publicado pelo honrado e político Sr. Luiz Augusto May, Digno Representante da Nação Brasileira, e por eles conhecerão nossos leitores quais os fins da fingida moderação; ele não é escrito por um anarquista, mas sim por o Ilustre Redator da Malagueta, conhecido por seus não interrompidos fatos por amigo do Brasil e que como tal tem sido duas vezes assassinado (sic), sem que a moderação amiga da Lei

o tenha vingado ${ }^{23}$.

O Diário de Pernambuco anunciou previamente a circulação deste jornal, explicando ao leitor que o título da folha seria alusivo "a aquela bandeira que o Diabo apresentou a um alfaiate na hora da morte, por conter todos os retalhos de panos de que ele se utilizara sem consentimento de seus donos; porque será composta de pedaços de todas as folhas livres do Império" ${ }^{24}$.

A multiplicação do número de periódicos - que na Corte passa de 53 folhas em 1831 para 81 em $1833^{25}$ - indica um crescimento do público leitor em virtude do incremento da demanda por essas publicações. Assim sendo, não obstante a perpetuação da censura, em particular ao se tratar de temas correlatos às formas de governo, a imprensa se revela como principal fonte para o estudo da difusão dos princípios doutrinários na primeira metade do século XIX. A leitura dos jornais permite entrever não apenas a singularidade de uma linguagem marcada pela redefinição semântica dos conceitos políticos, mas também pelo caráter pedagógico do qual se reveste a imprensa no âmbito da conformação da esfera pública no período regencial. Em Pernambuco, as novas leis, especialmente a instituição do Juizado de Paz, os protestos nas ruas, a atuação das sociedades públicas ou secretas e, sobretudo, a edição de novas folhas articuladas às correntes políticas ${ }^{26}$ adquirem um significado tão particular quanto explosivo. No entanto, para a compreensão dessa conjuntura, é preciso recuar aos últimos anos do Primeiro Reinado.

Em artigo indispensável para a investigação da dinâmica do processo eleitoral ante o impacto das mudanças institucionais, Marcus Carvalho chama a atenção para os conflitos ocasionados pela justaposição das atribuições do Juizado de Paz com as dos antigos corpos de ordenanças e milícias em Pernambuco ${ }^{27}$.Lembra o mesmo autor que a nomeação para a presidência da província em 1828 do

\footnotetext{
${ }^{23}$ Bandeira de Retalhos, n. II, 31 de janeiro de 1832. Grifado no original. O redator se refere aqui aos atentados contra o redator da Malagueta, ocorridos em 6 de junho de 1823 e 26 de agosto de 1829. Agradeço a Marcello Basile pela informação.

24 Diário de Pernambuco, n. 295, 25 de janeiro de 1832.

${ }^{25}$ Números extraídos de BASILE, Marcello. Inventário analítico da imprensa periódica do Rio de Janeiro na Regência: perfil dos jornais e dados estatísticos. In: CARVALHO, José Murilo de; NEVES, Lúcia M. Bastos P. das (org.). Dimensões e fronteiras do Estado brasileiro nos Oitocentos. Rio de Janeiro: Eduerj, 2014. p. 43.

${ }^{26}$ Luiz do Nascimento identifica em 1831 o aparecimento de oito novos jornais em Pernambuco. No ano seguinte começam a circular 14 novos periódicos em Recife. NASCIMENTO, Luiz do. História da imprensa de Pernambuco (1821-1954). Recife: UFPE, 1969. vol. IV, p. 79 ess.

${ }^{27}$ CARVALHO, Marcus J. M. de. Aí vem o capitão-mor: as eleições de 1828-30 e a questão do poder local no Brasil imperial. Tempo, Universidade Federal Fluminense, Departamento de História, vol. 7, n. 13, 2002.
} 
ex-auditor militar do inquérito movido contra os rebeldes de 1824, Thomaz Xavier Garcia de Almeida, teria assegurado o controle das eleições gerais no ano seguinte para juízes de paz, vereadores, membros do Conselho de Governo e deputados provinciais ${ }^{28}$. Nesse contexto, impactado ainda pela iminência do fim do comércio africano de escravos, dois movimentos, provavelmente articulados e praticamente simultâneos, viriam a ocupar as páginas dos jornais pernambucanos. O primeiro começou quando

um grupo de perversos (...) tiveram (sic) a criminosa audácia de marchar dos Afogados, arrabalde desta Cidade e, passando pela Várzea e Jaboatão, declaravam que iam à Vila de Santo Antão a instalar um Governo Republicano: uniram-se-lhes ali alguns desgraçados, como eles bandidos e sem nome e, com efeito chegados em no de 80 a

Santo Antão (...) procuravam formalizar o seu cerebrino Governo ${ }^{29}$.

Para tanto, depuseram as autoridades locais, apoderaram-se das armas do quartel e invadiram a cadeia pública libertando os presos. No dia seguinte, pretenderam reunir a Câmara no intuito de nomearem um novo governo. Ao que tudo indica, a revolta contou com o apoio e a participação de libertos e de escravos, em virtude da divulgação de boatos que asseguravam que com a "abolição do tráfico da escravatura, tornariam à escravidão todos os homens de cor libertos, o que concorreu para haver uma quase comoção na freguesia de Ipojuca". O mesmo ofício alertava que agentes do governo nos Estados Unidos e na Inglaterra advertiam que, em direção à província, partiram "alguns dos principais cabeças da revolução de 1824 que haviam sido banidos e sentenciados à morte". Afiançava também que "papéis incendiários (...) se afixaram na [província] do Maranhão, apontando-se o distrito de Pastos Bons como o lugar onde deveria ser proclamado o sistema republicano"30.

Ao participar a dispersão dos revoltosos ao ministro da Justiça, o ouvidor do crime Gustavo Adolfo de Aguilar procurou minimizar o episódio chamando-o de "comédia republicana". Asseverava que embora os revoltosos continuassem a marcha para o sertão no termo de Cimbres, em direção à fazenda do Jatobá, teriam sido

...desamparados por alguns outros dos sócios; (...) e finalmente em o dia 9 pela manhã foram depois dispersos poucas léguas adiante daquela Povoação por [ileg.] de Ordenanças e perseguidos pela tropa regular mandada pelo Governo, alguns foram presos, o resto fugiu em debandada, deixando no mato armas, cartuchame e outros gêneros de guerra. Terminada assim a Comédia Republicana, remeteu o Ex ${ }^{\mathrm{mo}}$ Presidente da Província ao $\mathrm{Ex}^{\mathrm{mo}}$ Governador os documentos originais acerca da referida Rebelião $0^{31}$.

Todavia, a "comédia republicana" chamou a atenção do Conselho de Estado que aprovou, na 24a sessão de 26 de fevereiro de 1829, a "suspensão das formalidades que garantem a liberdade individual naquela Província para serem presos e tratados como rebeldes os que nela se achassem implicados"32. Com efeito, no dia seguinte, o imperador emitiu decreto anuindo à sugestão do Conselho de Estado.

O segundo movimento da mesma sorte, iniciado no dia 2 de fevereiro e associado pelas autoridades à revolta da vila de Santo Antão, se restringira, ao que parece, à cidade do Recife. Conforme o relato dos ofícios redigidos pela Ouvidoria do Crime, "no dia 2 amanheceram pregados nas esquinas das ruas da Cidade vários Pasquins ${ }^{33}$ sediciosos, concitando o Povo à rebelião, que continuaram a aparecer nos três dias subsequentes" 34 . Imediatamente foi realizada a "ata Judicial de achada" e aberta uma devassa,

\footnotetext{
28 Idem, p. 159.

${ }^{29}$ Ofício do desembargador ouvidor geral do Crime da Relação, Gustavo Adolfo de Aguiar, ao ministro da Justiça, Lucio Soares Teixeira de Gouvêa, 7 de fevereiro de 1829. Acontecimentos em Pernambuco para inaugurar uma republica, 1829. Divisão de manuscritos da Biblioteca Nacional.

${ }^{30}$ Ofício de Lúcio Soares Teixeira de Gouveia a Joaquim Marcelino de Brito, 5 de maio de 1829. Citado por COSTA, Francisco A. Pereira da. Anais Pernambucanos. Pernambuco: Arquivo Público Estadual, 1965. vol. IX (1824-1833). p. $306 / 307$.

${ }^{31}$ Ofício de Gustavo Adolfo de Aguilar sobre a rebelião republicana ocorrida em Pernambuco. Recife, 30 de março de 1829. Divisão de manuscritos da Biblioteca Nacional.

32 Atas do Conselho de Estado. Brasília: Gráfica do Senado Federal, 1973. vol. 2, p. 67-69.

${ }^{33}$ A palavra pasquim também significava à época "sátira por escrito pregada nas ruas ou portas". SILVA, Antônio de Moraes. Diccionário da língua portuguesa ... Lisboa: Typographia de Antônio Jose da Rocha, 1858.

${ }^{34}$ Ofício do desembargador ouvidor geral do Crime da Relação, Gustavo Adolfo de Aguilar, ao ministro da Justiça, Lucio Soares Teixeira de Gouvêa, 7 de fevereiro de 1829. Acontecimentos em Pernambuco para inaugurar uma republica, 1829. Divisão de
} dossiê Regência e Imprensa 
amparada no Aviso de 20 de setembro do ano anterior que previa restrições à liberdade de imprensa. Em pouco tempo, menos de dois meses, a devassa dos pasquins já havia sido concluída ${ }^{35}$, mas, ao contrário da revolta iniciada em Afogados, da qual teria participado a população pobre da periferia, naquela foram implicados vários redatores de jornais, como o fundador do Diário de Pernambuco, Antonino Joze de Miranda Falcão, os ex-colaboradores de Paes de Andrade em 1824, Antônio Elias de Moraes e Joze Tavares Gomes da Fonseca, o fiscal de posturas do bairro de Santo Antônio e sobrinho de Cipriano Barata, Rodolfo João Barata, Antôonio Joaquim de Mello, Francisco Xavier Pereira de Oliveira, Francisco Joze de Veraz e Joze Machado Freire ${ }^{36}$.

Na opinião de Marcus Carvalho, a República dos Afogados e a panfletagem que se seguiu na cidade tinham por objetivo primordial influenciar o resultado das eleições para vereadores e deputados provinciais, além de refletir o conflito jurisdicional entre os capitães-mores e os juízes de paz. O autor lembra que a eleição comprovara o prestígio dos ex-participantes da Confederação do Equador, pois mesmo estando presos teriam sido sufragados para a Câmara Municipal Antônio Elias de Moraes e Antônio Joaquim de Mello, sendo este o segundo candidato mais votado ${ }^{37}$. No entanto, a constante alusão dos jornais ao longo de 1829 aos dois episódios evidencia a centralidade da imprensa como guardiã da memória da Confederação do Equador, compreendida por muitos como a legítima reação da província ao "despotismo" do imperador ${ }^{38}$.

\section{A Sociedade Federal de Pernambuco: impressos e atividade política}

Pelo que se sabe, a primeira Sociedade Política Federal foi criada em Pernambuco. No dia 15 de outubro de 1831 o Diário de Pernambuco imprime um aviso convocando a população para a instalação da Sociedade Federal a se realizar no dia seguinte, domingo, às 10 horas da manhã na igreja de Nossa Senhora da Conceição dos Militares em Recife. O jornal assegurava que as sessões seriam públicas e previamente divulgadas pela imprensa ${ }^{39}$. $\mathrm{Na}$ sessão inaugural parece ter havido "grande concurso de expectadores", conforme registra o mesmo periódico, comparecendo 43 sócios, entre os quais o juiz de paz suplente do bairro de Santo Antônio, João Arcênio Barboza e o comandante das Armas, brigadeiro Francisco de Paula Vasconcelos ${ }^{40}$, este último escolhido como vice-presidente da Sociedade. Nesse dia também foram eleitos o presidente, João Joze de Moura Magalhães, lente do Curso Jurídico de Olinda ${ }^{41}$, o primeiro e o segundo secretários, respectivamente Jose Tavares Gomes da Fonseca e José Lúcio Correia, além do tesoureiro, José Elesbão Ferreira.

manuscritos da Biblioteca Nacional.

${ }^{35}$ Sobre a Devassa dos Pasquins e o depoimento das testemunhas ver FONSECA, Silvia P. de B. A ideia de República... Op. Cit., 2016. cap. 7.

${ }^{36}$ Relação dos Reus pronunciados na Devassa dos Pasquins que se acham presos. Divisão de Manuscritos da Biblioteca Nacional. O mesmo documento informa que Joze Tavares Gomes da Fonseca já havia sido condenado "às obras do Dique por ter sido Emissário de Carvalho à Bahia".

37 "Em todos estes conflitos do final dos anos vinte fica clara a preocupação dos capitães-mores em exercer suas atribuições, arranhadas pela criação da Justiça de Paz, mas que estavam efetivamente esvaziadas a partir do momento em que havia tropas sob o comando de oficiais de primeira linha, fazendo rondas nas vilas do interior e seus arredores. Quebrava-se uma longa tradição luso-brasileira de deixar às milícias locais a vigilância da ordem em troca de uma adaptação que quase despersonalizaria o modelo anglo-saxão da justice of peace". CARVALHO, Marcus. Aí vem o capitão-mor... Op. Cit., 2002. p. 175 e 177.

38 Sobre a Devassa dos Pasquins ver também no Instituto Arqueológico Histórico e Geográfico de Pernambuco o manuscrito Devassa instaurada pelo crime de distribuição de pasquins sediciosos (...). Recife: Instituto Arqueológico Histórico e Geográfico Pernambucano, 1829. Agradeço ao historiador Marcus Carvalho pela indicação do documento.

39 Diário de Pernambuco, n. 220, 15 de outubro de 1831.

${ }^{40}$ O brigadeiro Francisco de Paula Vasconcelos, irmão do major Miguel de Frias e Vasconcellos, redator do periódico fluminense exaltado A Voz da Liberdade, nasceu no Rio de Janeiro em 1787. Aos dezesseis anos assentou praça no $1^{\circ}$ Regimento de Cavalaria e, três anos depois, foi nomeado tenente de artilharia e de fortificações em Angola. Em 1816, já capitão, assume o cargo de lente da Escola Militar do Rio de Janeiro, da qual se tornou posteriormente diretor. BLAKE, Augusto V. A. Sacramento. Diccionario bibliographico brazileiro. Rio de Janeiro: Imprensa Nacional, 1900. vol. III, p. 84. Segundo Manuel Correia de Andrade, a nomeação de Francisco Vasconcelos para o comando das Armas em Pernambuco visava afastá-lo dos federalistas do Rio, entre os quais exercera notável liderança por ocasião do 7 de abril. Cf. ANDRADE, Manuel Correia de. Movimentos nativistas em Pernambuco: setembrizada e novembrada. Recife: Universidade Federal de Pernambuco, 1971. p. 104. Deve-se lembrar que, por ocasião da instalação da Sociedade Federal em Pernambuco, o major Miguel de Frias liderava a revolta da ilha das Cobras no Rio de Janeiro.

${ }^{41}$ Segundo Pereira da Costa, alguns dias depois, retirou-se da província o dr. Moura Magalhães, sendo substituído na presidência pelo padre João Barboza Cordeiro, redator da Bussola da Liberdade. COSTA, Francisco Augusto Pereira da. Anais Pernambucanos. Recife: Arquivo Público Estadual, 1965. vol. IX, p. 445. 


\begin{abstract}
...uma oração, em que expôs os fins da Sociedade, que são a discussão da necessidade da Federação e dos meios de a conseguir quanto antes sem ilegalidades e perturbações [o que] satisfez completamente a expectativa dos sócios e (...) procedeu-se à leitura dos Estatutos (...) levantando-se esta primeira sessão e marcando-se para as quintasfeiras à tarde e Domingos de manhã as sessões ordinárias ${ }^{42}$.
\end{abstract}

Até dezembro o Diário de Pernambuco e também a folha Búussola da Liberdade transcreveram as atas das sessões da Sociedade. Como é conhecido, o primeiro fora fundado por Antonino Joze de Miranda Falcão que, após ser demitido da Tipografia Nacional em função de seu comprometimento com a Confederação do Equador, estabeleceu em 1825 uma tipografia em Pernambuco, denominada Miranda \& Companhia. Nesse mesmo ano iniciou a publicação do Diário de Pernambuco, de cuja redação participou até $1837^{43}$. Quanto à Bússola, circulou regularmente entre 1831 e 1832, duas vezes por semana, publicando três números extraordinários em 1835. Impresso na tipografia do Diário em 1831 e na tipografia Fidedigna no ano seguinte, o periódico foi criado e redigido pelo padre João Barboza Cordeiro, ativo participante da Revolução de 1817 no Rio Grande do Norte, onde obteve nomeação como vigário. Após ser preso, quando fugia para a Paraíba, foi remetido a Pernambuco e, posteriormente, à Bahia, onde permaneceu até a anistia em 1821.

A Bússola da Liberdade, além de publicar extensos artigos em favor da federação, discorrer a respeito das diferentes experiências históricas de associações entre monarquias e repúblicas, registrava a própria constituição da Sociedade, como o debate acerca dos estatutos, a eleição do Conselho, e a importância que a agremiação alcançara com a ampliação do número de sócios. Em sua terceira sessão, ocorrida em 23 de outubro, na qual estavam presentes 32 sócios, a Federal escolheu seu conselho, eleito a partir da lista inicial de sócios ${ }^{44}$.

Os dois primeiros meses de funcionamento da Sociedade Federal são praticamente dedicados aos assuntos pertinentes à elaboração do periódico, como a escolha do redator, a forma de distribuição e a tiragem. Na sessão de 9 de novembro, a comissão encarregada desse tema propõe que o jornal "se há de publicar por conta da Sociedade, segundo o art. 28 dos seus Estatutos", deverá ser "impresso em formato grande, sair uma vez por Semana, para ser distribuído gratuitamente por entre a classe mais necessitada de ilustração sobre a matéria". O redator da folha seria designado pela Sociedade, observando que a implementação das reformas federais apenas seria dirigida de acordo com os preceitos legais e no âmbito do Legislativo, "única Autoridade legítima para decretá-la", de acordo com $\mathrm{o}$ art. $2^{\circ}$ dos Estatutos ${ }^{45}$. Contudo, os associados divergiram sobre a gratuidade do jornal. Ponderava a comissão, representada por Miranda Falcão, que o desinteresse dos vendedores poderia prejudicar a regularidade na distribuição da folha.

Pelo que a Comissão era de parecer que a metade dos Impressos fosse distribuída por uma Comissão com certas e determinadas pessoas e a outra metade fosse exposta à venda pelo preço médio dos demais Periódicos: assim como que a Sociedade fixasse o número de Exemplares que se deveriam imprimir ${ }^{46}$.

Após alguma polêmica, ficou decidido que apenas os sócios receberiam gratuitamente o jornal. O preço a ser cobrado também foi objeto de discórdia, oscilando as propostas entre 80 e 40 réis, sendo finalmente aprovado o valor mais baixo. Quanto ao número de exemplares, "foi fixado o de 500 para

\footnotetext{
42 Diário de Pernambuco, n. 222, 18 de outubro de 1831.

${ }^{43}$ Antonino Jose de Miranda Falcão nasceu em Pernambuco a 10 de maio de 1798. Desde 1823, ocupara diversos cargos na província, entre os quais o de professor de primeiras letras, diretor da tipografia nacional, secretário do governo de Sergipe, cônsul geral do Brasil nos Estados Unidos, a despeito dos 18 meses que passara preso na Fortaleza de Brum pela participação no movimento de Santo Antão em 1829, relacionado naquele momento à chamada Devassa dos Pasquins. COSTA, Francisco Augusto Pereira da. Diccionario biográphico de pernambucanos célebres. Recife: Typographia Universal, 1882.

44 Bússola da Liberdade, n. 36, 23 de outubro de 1831.

${ }^{45}$ Sobre os estatutos e a lista parcial de sócios da Sociedade Federal de Pernambuco ver FONSECA, Silvia. A ideia de República... Op. Cit., 2016.

${ }^{46}$ O Federalista n. 1, 30 de dezembro de 1831
} 
cada Número, sujeito às alterações que para o diante se oferecerem" ${ }^{47}$.

Os Estatutos da Sociedade Federal de Pernambuco consignavam que esta será "composta de Cidadãos Brasileiros conhecidos por amantes da Liberdade", sem limitação de número. Os candidatos deveriam ser indicados por um sócio, observando sua afinidade com os propósitos da associação. Todavia, para decidir a respeito do ingresso do pretenso sócio, a Sociedade constituiria um conselho de 12 membros, o qual, "na sessão seguinte a da proposição, apresentará o resultado dos seus trabalhos, aprovando ou desaprovando os Candidatos propostos"48. O cadastramento dos sócios parecia ser preocupação primordial da agremiação, uma vez que o secretário estaria encarregado de elaborar e atualizar um livro de matrículas, "em que serão escritos os nomes de todos os Sócios, empregos e residências, assim como se fará declaração do dia, mês e ano da sua admissão e demissão, quando houver de desligar-se da Sociedade" ${ }^{49}$. Apesar da escassez de dados que demonstrem com precisão a trajetória política da Sociedade Federal de Pernambuco, há fortes indícios de que a associação se notabilizou tanto pela organização, ao criar diversas comissões encarregadas de tarefas específicas, quanto pela combatividade, de vez que atuou na mediação de conflitos armados decorridos em Recife em 1831.

Já no dia da sessão inaugural da Sociedade, a Bússola da Liberdade publicou um longo artigo, intitulado Como ou de que modo se deve proclamar a Federação, elaborando verdadeira pauta de assuntos a serem examinados nas sociedades públicas, notadamente as federais. Julgava que, ao invés de 18 províncias desiguais, fossem constituídos seis Estados ${ }^{50}$. Além da recomposição política e administrativa do Império, a afirmação veemente da legalidade da Sociedade Federal ocupava as folhas que representavam a associação, divulgando suas atividades. Outra estratégia de sobrevivência da agremiação recaía na dissociação entre federação e república. Para tanto, os articulistas recorriam aos "exemplos históricos", aludindo às associações antigas e modernas como a "célebre Federação das cidades gregas, conhecida pelo nome de Liga Anfictiônica e a Confederação Germânica, a mais citada como modelo de federação monárquica ${ }^{51}$.

O contexto político que informou a instalação da Sociedade Federal em outubro foi marcado por duas revoltas militares em Recife que, embora comportassem motivações distintas, no espaço de dois meses mobilizaram muitos daqueles que tomariam parte na associação. Conforme o depoimento do comandante das Armas, publicado no Diário de Pernambuco, na noite de 14 de setembro de 1831, toda

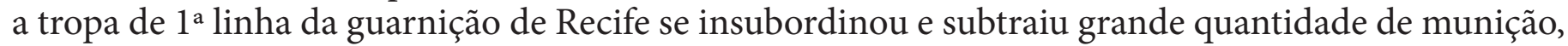
além de peças de artilharia, o que lhe permitiu controlar rapidamente boa parte da cidade ${ }^{52}$. Pelo que foi possível averiguar, os revoltosos não formalizaram nenhuma exigência concreta, a despeito do elevado número de soldados envolvidos, limitando-se a proferir morras ao comandante. O conflito se desdobrou em saques e incêndios na cidade ao longo de três dias, dos quais resultaram inúmeras vítimas. Pereira da Costa assegura que mais de mil pessoas foram presas a bordo das embarcações ${ }^{53}$. De acordo com Manuel Correia de Andrade, a Setembrada, que não contou com a participação de nenhum oficial, teria por motivação as duras condições a que eram submetidos os soldados, como o recrutamento forçado e os castigos corporais. Também provocavam grande indignação os atrasos frequentes nos pagamentos, muitas vezes efetuados com moedas de cobre, recusadas no comércio por serem falsificadas com facilidade. Refuta o autor, portanto, o caráter "restaurador" atribuído ao movimento por seus adversários ${ }^{54}$. Entretanto, alguns indícios sugerem o contrário. No dia 17 de outubro, o Diário de Pernambuco divulgou uma correspondência assinada sob o pseudônimo "Chancham", onomatopeia empregada para designar as moedas de cobre, na qual se relacionam os distúrbios militares em várias províncias às atividades supostamente restauradoras dos colunas ${ }^{55}$.

\footnotetext{
47 Idem. Ata da sessão de 22 de dezembro de 1831.

48 Bússola da Liberdade, n. 47, 11 de dezembro de 1831.

${ }^{49}$ Idem.

50 Bússola da Liberdade, n. 32, 16 de outubro de 1831.

51 O Federalista, n. 4, 28 de janeiro de 1832.

52 Diário de Pernambuco, n. 202, 23 de setembro de 1831

53 COSTA, Pereira da. Anais pernambucanos. Op. Cit, vol. IX, p. 425.

54 ANDRADE, Manuel Correia de. Movimentos nativistas em Pernambuco: setembrizada e novembrada. Op. Cit., p. 77.

55 Denominação atribuída aos caramurus em Pernambuco.
} 
Não há dúvida que a insubordinação da Tropa que tem causado contínuas desordens no Rio de Janeiro, na Bahia, aqui mesmo e em todo o Brasil é efeito de um plano concertado entre o ex-Imperador do Brasil e restos da nefanda coluna (...). Foi pois em virtude disto que a Tropa insubordinou-se na noite do dia 14 e nos dias 15 e 16 do passado ${ }^{56}$.

A sedição teria, por outro lado, servido como pretexto para destituir o comandante das Armas Francisco de Paula Vasconcellos. O episódio seria lamentado pela folha Bússola da Liberdade:

Quando principiamos a gozar alguma tranquilidade e o espírito público parecia progredir em harmonia pela convicção de que desejávamos todos evitar revoluções e marchar em ordem para o conseguimento (sic) da mais importante Reforma (a Federação) em o competente tempo que a Lei marca, eis que repentinamente chega uma ordem da Regência ao Sr. Presidente para tirar o Comando das Armas ao Sr. Brigadeiro Francisco de Paula Vasconcellos, herói do Dia 7 de Abril (...) para entregar ao Snr. Coronel Francisco Jacinto Pereira, miliciano que, segundo a voz pública, não goza da melhor opinião ${ }^{57}$.

O jornal Bandeira de Retalhos ajuizava que uma das razões da Setembrada era a retaliação contra o brigadeiro Paula pelo seu empenho na reintegração dos oficiais que haviam participado da Confederação do Equador: "e assim tivessem pão para manter seus filhos e esposas há 7 anos reduzidas à miséria" 58 .

Dois meses após a Setembrada eclode outro movimento militar em Recife. Na noite de 15 de novembro "cento e tantas pessoas" armadas, segundo a imprecisa narrativa do redator do Diário de Pernambuco, se reuniram na fortaleza das Cinco Pontas comandadas pelo capitão Antônio Afonso Viana, português que estivera a serviço da República de Buenos Aires na guerra da Cisplatina, secundado pelo tenente João Machado Magalhães. O grupo enviou em 36 horas uma representação, assinada por Anastácio Jose dos Passos, ao governo da província na qual exigia a demissão e deportação de indivíduos considerados "absolutistas" pelo vínculo com a repressão aos movimentos federalistas e republicanos desde a independência. Reclamavam também a proibição das sociedades estrangeiras, a expulsão dos portugueses solteiros pobres, assim como o confisco das armas dos milicianos lusitanos ${ }^{59}$. O documento acusava a sociedade secreta Coluna do Trono e do Altar ou seus herdeiros de planejar os distúrbios de setembro e de pretenderem o retorno do ex-imperador. Entre aqueles cuja expulsão da província era exigida, quase todos militares, figuravam alguns indivíduos responsáveis pelo aniquilamento da Confederação do Equador, como o coronel Bento Jose Lamenha Lins, Francisco Paes Barreto, além dos ex-membros da comissão militar instaurada no Ceará em 1824 e 1825: Manoel Pedro de Moraes Mayer e o major e engenheiro alemão, naturalizado brasileiro, João Bloem. Vale aduzir o nome do capitão-mor Domingos Lourenço Torres Galindo, encarregado da perseguição aos implicados na Revolta de Santo Antão.

O presidente da província, Francisco Paes de Andrade, irmão do líder da Confederação do Equador, alegou não poder atender às reivindicações por estarem fora de sua alçada, além de serem consideradas inconstitucionais. Diante do impasse, imediatamente a Sociedade Federal se prontificou a intermediar o conflito: constituiu uma comissão que se dirigiu à fortaleza das Cinco Pontas e solicitou aos revoltosos "que depusessem as Armas e fizessem as suas representações pelos meios marcados pelo (...) Código Fundamental" 60 . Os rebeldes então recuaram e restringiram suas demandas ao confisco das armas dos portugueses, à deportação dos que não preenchessem as condições anteriormente apontadas, além da anistia à revolta. A Sociedade Federal se reuniu no dia 18 de novembro e decidiu requerer ao governo provincial a aceitação das exigências. Todavia, o governo não anuiu às reivindicações dos

\footnotetext{
${ }^{56}$ Diário de Pernambuco, n. 221, 17 de outubro de 1831.

${ }^{57}$ Bussola da Liberdade, n. 37, 2 de novembro de 1831. O coronel Francisco Jacinto Pereira comandou a expedição encarregada de sufocar a Revolta de Santo Antão em 1829 e prendeu seus implicados.

58 Bandeira de Retalhos, n. 3, 7 de fevereiro de 1832.

${ }^{59}$ A Representação foi publicada no Diáario de Pernambuco, n. 251, 25 de novembro de 1831. Foi anexada à petição a relação de nomes a serem "demitidos" ou enviados "para fora da Província".

${ }^{60}$ Diário de Pernambuco, n. 251, 25 de novembro de 1831.
} 
revoltosos, intimando-lhes que se rendessem imediatamente. Segundo a narrativa do correspondente anônimo do Diário de Pernambuco, no dia 18 houve choques entre eles e o povo armado, reunido no bairro do Recife, dos quais resultaram algumas mortes e ferimentos. "Empregando-se afinal o respeito dos meios de pacificação e desenganados os da Fortaleza da sua impotência e de que arrostavam a opinião Pública, começaram a debandar-se e à noite achava-se evacuada a Fortaleza e restabelecida a tranquilidade desta Cidade" 61 .

\section{Além do diário pernambucano, também a Gazeta da Bahia registrou a sublevação militar em Recife:}

\section{Notícias de Pernambuco}

Pelo Paquete Inglês chegado de Pernambuco, com dois dias e meio de viagem, sabemos que ficava restabelecido naquela Província o sossego público. O que podemos saber por notícias de um passageiro (...) foi que na noite do dia 15 deste Mês começaram os rebeldes a reunir-se na fortaleza das cinco pontas; (...) tendo engrossado em $\mathrm{n}^{\circ}$ principiaram com absurdas requisições, tais como saída de Portugueses solteiros, e casados de 1824 para cá, deposição de vários Juízes de Paz e outros Empregados; no entanto dava o Governo as mais enérgicas providências, fazendo reunir os Guardas Municipais para os atacar. (...) o que sabido pelos rebeldes os desanimou a ponto de se porem em fuga, sendo contudo presos muitos deles. Julga-se não haver mais que duas ou três mortes ${ }^{62}$.

No ano seguinte, ao encetar a publicação do célebre $O$ Carapuceiro, periódico sempre moral e só per accidens político, padre Miguel do Sacramento Lopes Gama ${ }^{63}$ comentou, a seu modo, as sublevações militares em Recife, decorridas no ano anterior. Os olhos do cronista e sua verve satírica nos conduzem a um tempo e a um lugar nos quais o exercício da política se propaga por quase todas as camadas da sociedade recifense. A despeito das referências ao passado, talvez seja este o traço distintivo do período regencial. Em Pernambuco, passado, presente e futuro se fundiam na memória e nos anseios daqueles que viveram anos tão conturbados e se desdobravam no debate político cotidiano nas tipografias, boticas, barbearias e botequins:

Qual é o motivo porque todas as sedições, chamadas agora rusgas, que aqui tem havido, são formadas no Recife ou em alguma das vilas? Claro está que é porque nestes lugares, por mais populosos apinham-se muitos calaceiros e vadios, o que não acontece pelos campos, cujos moradores, ocupados pela maior parte nos inocentes e agradáveis desvelos da Agricultura, não lhes sobra o precioso tempo para papaguearem em Política e arquitetarem revoluções.

Com efeito, enjoa ver por este nosso mundo tanta gente ociosa e todos profundíssimos Políticos (...) O Alfaiate, em vez de estar em sua loja cortando panos e fazendo roupas, traz à corda os fregueses semanas e semanas; porque vive talhando Governos, gizando Constituições e alinhavando rusgas; o Sapateiro já não quer saber de couros e solas, só fala em Gazetas e não há Governo que não meta nas encóspias. Pois o Barbeiro que dá para Publicista! Isso é uma peste, é a nossa colera morbus. Se o mando chamar para me limpar os queixos, não há Reino de que não saiba notícias, não há Gabinete que não traga no estojo, não há novidade que não venha bem pronta e afiada (...)

E o que direi dos botequins? São outras tantas aulas de altíssimas disciplinas morais e políticas. (...) ali se discutem e decidem irremissivelmente as mais entremeadas questões de Direito Natural e de Direito Público. Rodeados de copos de café (...) ou com o ponche em punho e o indispensável palitinho nos dentes [ileg.] um Rousseau, um Voltaire, um Mably, um Helvecio, um Chateaubriand, um Benjamin Constant, um Royer-Collard. (...) Ali se lavram irrevogáveis sentenças sobre o mérito ou demérito dos Periódicos, sendo sempre aplaudidos aqueles que dão por paus e por pedras e os que dizem que o Povo pode fazer o que muito quiser. (...) Assim correm as horas, pela alta noite eclipsam-se estes astros, e de manhã hei-los outra vez no botequim, que é o seu Perigeu para continuarem no mesmo giro ${ }^{64}$.

\footnotetext{
61 Diário de Pernambuco, n. 247, 21 de novembro de 1831.

62 Gazeta da Bahia, n. 9, 24 de novembro de 1831.

${ }^{63}$ Sobre Lopes Gama ver FONSECA, Silvia Carla Pereira de Brito. A República em negativo: o sistema conceitual do padre Carapuceiro. Almanack, Guarulhos, n. 3, p. 99-115, junho de 2012. Disponível em http://www.scielo.br/scielo.php?script=sci_arttext\&pid=S223646332012000100099\&lng=en\&nrm=iso._Ver também, FELDMAN, Ariel. Espaço público e formação do Estado nacional brasileiro: a atuação política do padre Carapuceiro (1822 a 1852). Tese (Doutorado), Universidade de São Paulo, São Paulo, 2013. Idem. Guerra aos extremos: polarização política em Pernambuco e a defesa do princípio de soberania nacional (1829-1831). Almanack, Guarulhos, n. 7, p. 39-58, junho de 2014. http://www.scielo.br/scielo.php?script=sci_arttext\&pid=S2236-46332014000100039\&lng=en\&nrm=iso. 64 O Carapuceiro, n. 2, 14 de abril de 1832. Grifo no original.
} 


\section{Pernambuco: imprensa e Restauração}

Contudo, o espectro que rondava a imprensa e a Sociedade Federal a partir de 1832 consistia na crescente mobilização da facção caramuru, apelidada em Pernambuco de coluna em alusão à Sociedade da Coluna e do Trono criada em Recife em 1829, da qual participaram os redatores dos periódicos $O$ Cruzeiro e O Amigo do Povo, os padres Francisco Ferreira Barreto e Jose Marinho Falcão Padilha ${ }^{65}$. Na percepção dos federalistas e republicanos, mas também de muitos moderados, os colunas, caramurus, marotos, corcundas, pés-de-chumbo, papeletas ou marinheiros, conforme o registro local e histórico ${ }^{66}$, se organizaram nos primeiros anos da Regência tendo em vista promover o retorno de d. Pedro ao trono brasileiro.

A divulgação da notícia de que Antônio Carlos de Andrada teria pessoalmente convidado o eximperador, então duque de Bragança, a reassumir o trono no Brasil gerou igualmente inquietação na imprensa. Octavio Tarquínio de Sousa narra o episódio afirmando que, apesar da disputa pelo trono português, na qual se empenhara em favor de sua filha d. Maria II, d. Pedro impusera algumas condições para aceder ao convite. Ao estilo do Antigo Regime, exigia que as

Municipalidades expressem a vontade nacional, e que a Assembleia Geral declare solenemente que convém que eu volte ao Brasil para na qualidade de Regente o governar durante a menoridade do Imperador meu filho, e que a mesma Assembleia me envie uma deputação a dar-me parte da resolução e a pedir-me, ao mesmo tempo, que eu haja de anuir ao voto nacional, legalmente expressado ${ }^{67}$.

Convém acrescentar a este contexto a eclosão de várias revoltas populares no interior de Pernambuco, Ceará e Alagoas entre 1832 e 1835 que pleiteavam o retorno do ex-imperador. Tais movimentos, como a revolta de Pinto Madeira, a Cabanada e as Carneiradas ${ }^{68}$, seriam por vezes fomentados por oficiais caramurus que arregimentavam populações pobres do sertão. No entanto, ao longo do tempo, teriam adquirido dinâmica própria, visto que canalizavam a insatisfação popular em face da miséria e das desigualdades sociais ${ }^{69}$. Segundo Pereira da Costa, o fracasso das insurreições militares "restauradoras" na cidade em setembro de 1831 e em abril do ano seguinte, conhecida esta última como Abrilada, ensejou a interiorização dos movimentos que, para o autor, comungavam dos mesmos intuitos, dando início à Cabanada ou guerra dos Cabanos ${ }^{70}$. Contudo, a heterogeneidade de seus participantes, além da longa duração destas sedições sugerem a pluralidade e complexidade de seus intentos, de vez que perdurariam após a morte do duque de Bragança. De qualquer forma, real ou imaginária, a Restauração seria encarada não apenas como uma possibilidade concreta, mas bastante provável em vista da frequência e seriedade com que o tema é abordado na imprensa exaltada e moderada. Já na terceira edição do Carapuceiro, datada de 28 de abril de 1832, Lopes Gama abre o jornal com um artigo, no qual alerta para a ação política dos colunas em Pernambuco e comenta a Abrilada.

\footnotetext{
${ }^{65}$ Sobre os jornais O Amigo do Povo e O Cruzeiro ver FONSECA, Silvia Carla P de Brito. Em Pernambuco os que oram também lutam: a imprensa abatinada e seus embates conceituais (1829-1831). Pós-História, Assis, n. 13/14, 2005/2006.

${ }^{66}$ Para uma interessante análise das diferentes alcunhas dos caramurus ver MOREL, Marco. Restaurar, fracionar e regenerar a nação... Op. Cit., 2003.

${ }^{67}$ Citado por SOUSA, Octavio Tarquínio. História dos fundadores do Império do Brasil... Op. Cit., vol. 4, p. 1134. Grifado no original. Marco Morel faz também alusão ao mesmo assunto. Cf. MOREL, Marco. As transformações dos espaços públicos... Op. Cit., 2003 .p. 427. ${ }^{68}$ As Carneiradas foram lideradas pelos ex-sócios da Sociedade Federal, os irmãos Carneiro Machado Rios. Na relação de sócios da Sociedade Federal de 15 de agosto de 1833 ainda constam seus nomes.

69 A respeito do tema ver LINDOSO, Dirceu. A utopia armada. São Paulo: Paz e Terra, 1982.

70 "Esse partido a que chamavam Regressista tinha efetivamente como fins políticos a instituição de um novo império no norte do Brasil, cujo soberano seria o ex-imperador D. Pedro I (...) império que uns queriam que se chamasse Império do Equador outro Império do Amazonas e outros finalmente Império do São Francisco, vendo-se assim a delimitação das suas fronteiras territoriais. Esse partido em sua maior parte era composto de portugueses, muitos dos quais dispunham de alentada fortuna (...) A Cabanada (...) estabeleceu o seu centro de ação em Panelas de Miranda e a das Alagoas em Jacuípe. Vicente Ferreira de Paula, o chefe dos insurgentes em Pernambuco, via dia a dia aumentar o seu séquito com o concurso de gente que lhe chegava de várias localidades (...) entre os quais figurava um composto dos escravos dos engenhos (...) ao qual deram a particular denominação de Papa-mel. A esses escravos fora dada a promessa de sua alforria, finda a campanha”. COSTA Pereira da. Anais Pernambucanos... Op. Cit., p. $502,503$. 
Apesar de ter dedicado este meu pequeno periódico tão somente à Moral, todavia, como disse que per accidens trataria alguma cousa de Política, não devo passar por alto o horrível atentado da facção mais insolente que tem aparecido no Brasil, quero dizer, a rebelião dos ingratíssimos colunas. A generosidade mal assente do Governo, a desassisada tolerância dos liberais não foram capazes de desarmar o ódio desses perversos escravos à Sagrada Causa da Liberdade Brasileira. Inimigos desta no tempo do poderio do Déspota, que felizmente deixou-nos, conjurados para volver-nos ao jugo do absolutismo Português, a queda do Tirano, o desbarato de suas tentativas não foram bastantes a quebrantar-lhes os ânimos e porfiosos continuaram em seus planos infernais, até que desmascararam-se de todo e deram o grito da revolta em a noite do dia 14 do corrente mês de Abril. (...)

O batalhão 53, composto quase todo de gente Europeia, e parte do 54 ejusdem furfuris ${ }^{71}$ assenhorearam-se da fortaleza do Brum e dominaram por um dia e uma noite (não é pequena glória) o bairro de S. Fr. Pedro Gonçalves e toca a fazer fogo a torto e a direito para Santo Antonio e Boavista (...) e no mesmo ponto o botecudo (sic) Pinto Madeira (que é um Gengis Khan dos Cariris) pelo centro (...)

Os homens já tem uma evasiva quando (...) forem ou estiverem para ser agarrados, que fizeram tudo isso para se oporem à Sociedade Federal (...)

Os infames foram batidos e destroçados em menos de 24 horas $^{72}$.

Em 25 de julho de 1833, a Sociedade Federal convocou uma sessão extraordinária na qual foi apoiada a criação de uma comissão, proposta pelo segundo secretário Jose Joaquim da Fonseca Capibaribe, destinada a elaborar um parecer "sobre as medidas que a esta Sociedade convém tomar para evitar o progresso do monstro da restauração que se permedita (sic) em favor do tirano Bragantino"73. A comissão seria composta pelo advogado Henrique Felix de Dacia, redator do semanário satírico Palmatoria dos Toleirões ${ }^{74}$, do coronel Jose de Barros Falcão, além do próprio Capibaribe. Nas duas sessões seguintes, em 28 de julho e 4 de agosto, persistiu o debate a propósito da mesma matéria e, a 15 de agosto, a Sociedade Federal divulgou uma proclamação, assinada por 121 sócios, além dos quatro administradores, na qual recomendou quatro medidas "de urgentíssima necessidade". Em primeiro lugar, julgava imprescindível, o quanto antes, "decretar-se o banimento do Duque de Bragança"75; em segundo lugar, "de se suspenderem (...) as formalidades garantidoras dos direitos individuais do Cidadão a respeito daqueles que por vias de fato e com as armas na mão, proclamarem a Restauração"; em terceiro lugar propunha "investir o Governo dos meios necessários para fortificar o litoral do Brasil"; e em quarto lugar sugeria aumentar e "engravescer-se as penas cominadas nos Artigos 68, 85, 87, 88 e 89 do Código Criminal"76.

\section{Imprensa e revoltas federalistas na Bahia}

Assim como ocorreu no Rio de Janeiro e em Pernambuco após o 7 de abril, também na Bahia sucederam movimentos de protesto, integrados em grande medida, mas não exclusivamente, por militares que exigiam a substituição do comando das armas, muitos ainda ocupados por oficiais portugueses. Tais manifestações de "povo e tropa" encontravam eco na imprensa, em meio às demandas pelas reformas na Constituição de 1824 que consignassem a autonomia política das províncias ${ }^{77}$.

Na Bahia, ao menos quatro sublevações galvanizaram os ânimos da tropa em 1831. A primeira, iniciada no dia 4 de abril, reuniu tropa e povo no Campo do Barbalho e divulgou um documento, transcrito pelos jornais Escudo da Constituição Brasileira e Gazeta da Bahia, no qual seriam denunciadas "violentas transgressões à Constituição" na província. Indignavam-se os amotinados com a prisão de

\footnotetext{
71 Do mesmo farelo, da mesma laia.

72 O Carapuceiro, n. 3, 28 de abril de 1832.

73 O Federalista, n. 37, 29 de agosto de 1833. Arquivo Público Estadual de Pernambuco Jordão Emerenciano.

74 Felix de Dacia também teria redigido o jornal A Voz do Povo Pernambucano que circulou em Recife e Olinda em 1833.

${ }^{75}$ Neste mesmo ano, o padre Venâncio Henrique de Rezende apresenta à Câmara dos Deputados um projeto de banimento do eximperador que "por poucos votos caiu”. COSTA. Pereira da. Diccionario biográphico de pernambucanos célebres... Op. Cit., p. 791.

76 O Federalista, n. 37, 29 de agosto de 1833.

77 Sobre o tema ver ARAS, Lina Maria Brandão de. A santa federação imperial. Tese (Doutorado), Universidade de São Paulo, São Paulo, 1995.
} 
dois oficiais brasileiros, "só pelo fato de serem Constitucionais e Defensores da Independência", que julgavam ameaçada pela "facção Lusitana recolonizadora", sediada no Rio de Janeiro. Reclamavam os revoltosos a deposição do marechal João Crisóstomo Calado, comandante das Armas, e a nomeação interina de um oficial "Brasileiro nato", a substituição de Manoel Joaquim Pinto Paca do comando da Polícia, além da prisão e expulsão da província do comandante do $2^{\circ}$ Batalhão e de todos os oficiais portugueses que não aderiram ao movimento. A lista de reivindicações foi entregue aos três negociadores, representantes do Corpo Legislativo, da Câmara Municipal e do Conselho do Governo. As exigências foram parcialmente atendidas, em particular aquelas relativas à substituição dos comandos das Armas e da Polícia, além da nomeação de uma comissão para indicar os portugueses a serem deportados ${ }^{78}$. O jornal $O$ Bahiano, redigido por Bernardino Ferreira Nobrega, sócio de Antônio Rebouças, publicou na edição do dia 12 de abril a resposta do presidente e do Conselho da província ${ }^{79}$. Pouco depois, conforme registro da folha Nova Sentinella da Liberdade na Guarita do Forte de São Pedro na Bahia de Todos os Santos do dia 2 de junho de 1831, o forte de São Pedro foi ocupado pelo batalhão Piauy. Os insurgentes insistiam na substituição do presidente da província, do comandante das armas interino, e também na deportação de portugueses. Ainda em 1831, um ofício do presidente da província, Honorato José de Barros Paim, dirigido ao ministro do Império José Lino Coutinho, participava "que o espírito de insurreição que desgraçadamente se manifestou na Tropa desta Capital em o dia 15 [de julho] (...) fora sufocado (...) conseguindo-se assim salvar a Dignidade Nacional e estabelecer a Ordem, a confiança, a união social" ${ }^{80}$.

No dia 28 de outubro ocorreria mais um levante militar no forte de São Pedro, seguido de sedição popular. Todavia, somente no ano seguinte as sublevações iriam assumir um caráter mais explicitamente federalista. Em fevereiro de 1832 ocorreu uma revolta na vila de São Félix, integrada por "algumas das cabeças das revoltas de 28 de outubro do ano passado que não chegaram a ser presos (sic)" e liderada pelo então juiz de paz do arraial, Bernardo Miguel Guanaes Mineiro. Em seguida à ocupação da Câmara Municipal de Cachoeira, foi nomeado um governo provisório e proclamado "o Governo Federal" mediante a divulgação de um manifesto, composto de 24 artigos ${ }^{81}$. Os insurgentes decretavam a instauração do "Governo Federativo" na Bahia, "para que esta Província, nos seus negócios internos e peculiares se governe independente de outra qualquer, fazendo, porém, aliança com todas as outras, bem como obedecendo ao Chefe principal da Federação dos Negócios Gerais da Nação, marcadas pela Assembléia Provincial". Também instituíam uma "Assembleia Legislativa Provincial, que será composta de 21 Membros ou Deputados, para marcar todos os limites da Independência da Província, suas relações com o chefe principal da Federação" ${ }^{2}$.

$\mathrm{O}$ "programa revolucionário" do movimento de 1832 requeria, da mesma maneira, uma reforma administrativa e judiciária, o fim da Lei de Imprensa de $1830^{83}$, a libertação dos presos "pela tentativa de Aclamação Federal de 28 de Outubro do ano próximo passado", bem como a extinção das "prisões em Navios ou Presigangas" ${ }^{\text {. N }}$. No entanto, em razão do bloqueio movido pelo presidente da província, Honorato Jose de Barros Paim, o abastecimento da vila de Cachoeira foi suspenso e em apenas uma semana a insurreição foi sufocada e presos os implicados, entre os quais Guanaes Mineiro e Domingos Guedes Cabral.

\footnotetext{
${ }_{78}$ Escudo da Constituição Brasileira, n. 38, 11 de abril de 1831. Gazeta da Bahia, n. 25, 8 de abril de 1831.

${ }^{79}$ O Bahiano, n. 37, 12 de abril de 1831. Ver também o jornal Escudo da Constituição Brasileira, n. 38, 11 de abril de 1831. Sobre a conjuntura política na Bahia no final do Primeiro Reinado e início da Regência ver SILVA, Daniel A. da. Na trilha das garrafadas: a abdicação de d. Pedro I e a afirmação da identidade nacional brasileira na Bahia. Análise Social, Lisboa, n. 203, p. 268-297, 2012. Do mesmo autor, ver: A duras e pesadas penas: imprensa, identidade e nacionalidade no Brasil imperial. Topoi, Rio de Janeiro, vol. 10, n. 19, jul.-dez. 2009 , p. $55-69$.

80 Correspondência do presidente da província da Bahia (1831-1832). Arquivo Nacional. Ofícios do Governo da Bahia.

${ }^{81}$ Correspondência do presidente da província da Bahia (1831-1832). Arquivo Nacional. Ofícios do Governo da Bahia, 21 de fevereiro de 1832. A proclamação foi anexada à correspondência do presidente da província e está datada de 17 de fevereiro de 1832. 82 Ibidem.

${ }^{83} \mathrm{Em} 20$ de setembro de 1830 fora editada nova lei "Sobre o abuso da liberdade de Imprensa" que consignava em seu segundo artigo: "Abusam do direito de comunicar os seus pensamentos os que por impresso de qualquer natureza emitirem: $1^{\circ}$ Ataques dirigidos a destruir o Sistema Monárquico Representativo, abraçado e jurado pela Nação e seu Chefe. Os responsáveis incorrem na pena de prisão de três a nove anos e na pecuniária de um a três contos de réis.; $2^{\circ}$ Provocações dirigidas a excitar rebelião contra a Pessoa do Imperador e seus direitos ao Trono". Coleção de Leis do Império do Brasil, 1830.

${ }^{84}$ Correspondência do presidente da província da Bahia (1831-1832).
} 
Nas Recordações patrióticas, Antônio Pereira Rebouças registrou os sucessos da revolta de 1832, qualificada pelo célebre advogado de "República de São Félix". No livro, dedicado ao conde d'Eu, consta uma nota preliminar informando que o texto fora ditado, e não escrito, por Rebouças em agosto de 1868, uma vez que o autor já se encontrava “então sem vista para ler e escrever".

Constando na capital da província da Bahia, em fevereiro de 1832 que, na povoação de S. Felix, fronteira à heróica cidade da Cachoeira, se havia aclamado República, achando-se já nomeada e em exercício a correspondente Entidade governativa, se dirigiu o Rebouças ao palácio do governo, e aí se achou tão somente com o presidente desembargador Paim. (...)

Felizmente a efêmera República de S. Felix existiu e finou incruenta ${ }^{85}$.

Todavia, pouco tempo depois, em 26 de abril de 1833, os prisioneiros recolhidos ao forte do Mar promoveram mais uma rebelião, controlaram a artilharia e ameaçaram bombardear a cidade, caso não fosse instaurado o "sistema federal" 86 . De acordo com o Diário da Bahia, após a rendição os amotinados hastearam a bandeira branca e retiraram o pavilhão federalista azul e branco. Posteriormente, foi enviado ao forte o tenente ajudante de ordens do comandante das Armas, Francisco Lopes Jequiriçá, para a prisão dos "figurados chefes da revolta, um célebre Daniel ${ }^{87}$ [Gomes de Freitas], o tenente Alexandre [Ferreira do Carmo Sucupira], autor da passada rusga de 8 de março e outros" 88 . Assim como ocorrera no ano anterior, divulgaram os rebelados um detalhado programa por meio de uma proclamação. Hendrik Kraay aventa a hipótese de Cipriano Barata ter tido influência na elaboração do documento, a despeito de não ter participado do conflito ${ }^{89}$. O conteúdo do manifesto era muito semelhante ao programa de 1832, notadamente em sua feição antilusitana. Dentre as reivindicações figuravam a não concessão de foro de cidadania brasileira aos portugueses, sua exclusão do comércio varejista, bem como a proibição do porte de armas. Alguns tópicos reclamavam também a demissão dos lusitanos dos cargos civis e militares, a deportação dos solteiros (à exceção dos empregados na lavoura), além da extinção das pensões concedidas por d. João VI ou por d. Pedro I ${ }^{90}$. Postulavam ainda os revoltosos do forte do Mar a libertação dos presos envolvidos com a Aclamação federal de 28 de Outubro de 1831 e com o movimento federalista de Cachoeira em 20 de fevereiro de 1832. Para além das reivindicações de natureza política, a proclamação previa a distribuição de riqueza entre os cidadãos livres, sobretudo da propriedade fundiária的. Um dos participantes da sublevação, Domingos Guedes Cabral, voltaria a tratar detalhadamente do tema no jornal O Democrata, que começou a circular após a sua libertação.

O Diário da Bahia, na edição de 30 de abril de 1833, imprimiu o comunicado do então presidente da província, Joaquim José Pinheiro de Vasconcellos, no qual informava a prisão dos rebelados que, no dia 26 do corrente, arvoraram uma "Bandeira diversa da Nacional Imperial e pratica[ram] hostilidades contra a Cidade e contra as Embarcações do Recôncavo, que demandavam o Porto"92.

\footnotetext{
85 REBOUÇ,AS, Antônio Pereira. Recordações patrióticas (1821-1838). Rio de Janeiro: Typ. G. Leuzinger \& Filhos, 1879. p. 99 e 100.

${ }^{86}$ Os líderes do movimento são, como no ano anterior, Bernardo Miguel Guanaes Mineiro, Alexandre Ferreira do Carmo Sucupira, Daniel Gomes de Freitas, Joaquim Giraldes, José de Vasconcellos, cônego Firmino. Ver VIANA FILHO, Luiz. A Sabinada (A República bahiana de 1837). Rio de Janeiro: Livraria José Olympio Editora, 1938. p. 56.

${ }^{87}$ Daniel Gomes de Freitas participou ativamente das lutas pela independência na Bahia aos 17 anos de idade e foi envolvido no processo que se seguiu à sublevação do chamado batalhão dos "Periquitos" em 25 de outubro de 1824. Apesar de sua absolvição em 1828, Gomes de Freitas foi preso por tomar parte no motim deflagrado em agosto de 1831, motivado pelo isolamento imposto aos militares, o que lhe custou a suspensão da promoção pela qual aguardava desde a década anterior. Após a revolta federalista de 1832, Daniel foi transferido para a fortaleza do Mar, junto aos demais acusados de cumplicidade com os movimentos liberais, onde liderou a sedição de abril de 1833. Sobre Gomes de Freitas ver KRAAY, Hendrik. Daniel Gomes de Freitas: um oficial rebelde do exército imperial brasileiro. Politeia: História e Sociedade, revista da Universidade Estadual do Sudoeste da Bahia, Vitória da Conquista, vol. 4, n. 1, p. 135-158. Agradeço ao autor pelo envio do artigo.

88 Diário da Bahia, n. 69, 30 de abril de 1833.

89 KRAAY, Hendrik. Daniel Gomes de Freitas... Op. Cit., p. 148.

${ }^{90}$ QUINTAS, Amaro. O Nordeste e a Bahia (1825-1850). In: CAMPOS, Pedro Moacyr; HOLLANDA, Sérgio Buarque de (org.). História geral da civilização brasileira. São Paulo: Difel, 1978. tomo I, $2^{\circ}$ vol, p. 277, 278.

91 KRAAY, Hendrik. Daniel Gomes de Freitas... Op. Cit., p. 149.

92 Diário da Bahia, n. 69, 30 de abril de 1833.
} 
O jornal elogiava a pronta ação dos soldados e oficiais de $1^{\text {a }}$ linha, em particular do tenente coronel português Luiz da França Pinto Garcez, e concluía que a ação partira, em grande medida, dos presos que se amotinaram no forte do Mar:

Durante os três dias de insurreição, a $1^{\text {a }}$ Linha, a saber, os Batalhões $3^{\circ}$ e de Artilharia, não somente serviram como lhes cumpria, porém igualmente suportou o mais rígido trabalho para o arranjo da bataria da Sé, a qual se tornava tanto maior quanto ridículos ou nenhuns eram os preparos existentes em nosso Trem de Guerra. (...)

Depois de tudo concluído tratamos de examinar o que se passou na Fortaleza durante a insurreição e a maneira porque foi perpetrada e podemos coligir tão somente que fora das prisões existiam alguns presos (...) esses que foram os Traidores que pretenderam assassinar o Comandante da Fortaleza ${ }^{93}$.

\section{A Sociedade Federal da Bahia}

Como foi mencionado anteriormente, há poucos registros sobre as sociedades políticas constituídas nos primeiros anos do período regencial. No caso da Sociedade Federal da Bahia, as parcas referências encontradas estão dispersas nos jornais. No dia 19 de dezembro de 1831, o Diáario de Pernambuco transcreveu artigo do Diário Baiense n. 70, datado de $1^{\circ}$ de dezembro, no qual é narrada sua fundação.

Ontem instalou-se na Sala de Sessões da Câmara Municipal desta Cidade a Sociedade Federal. Principiou a sessão às 10 da manhã e findou-se às 6 da tarde. (...) Foram eleitos Presidente o Sr. Doutor Moura e Vice Presidente o Sr. Doutor Ataliba, Primeiros Secretários os Snrs. Antunes e Pao Brasil. Há bem fundadas esperanças de que a Sociedade Federal muito contribuirá para de todo pacificar esta Província, chamando à ordem os desvairados ou iludidos. O número de Sócios com que se instalou excedeu a 80 e muito (sic) mais seriam se o dia não fosse tão chuvoso e houvesse tempo preciso para serem avisados os que já se consideravam Sócios que, dizem, excede a

$300^{94}$.

É importante reiterar a proximidade entre as sociedades políticas de diferentes províncias, corroborada pela frequência das notícias no Diário de Pernambuco a respeito da Bahia. Em fevereiro de 1832, o jornal pernambucano imprimiu um parecer da Sociedade Federal da Bahia datado de 24 de dezembro de 1831 e assinado pelo padre Vicente Maria da Silva, por Ignácio Accioli de Cerqueira e Silva e por Manoel Joaquim de Mattos ${ }^{95}$. No texto são narradas as deliberações da sessão de 18 de dezembro de 1831. A primeira trata de uma correspondência com a Sociedade Federal de Pernambuco e a segunda versa sobre outra comunicação com a Sociedade Patriótica, Instrutiva e Filantrópica da Província do Grão Pará. O teor do parecer enaltece a aproximação entre as associações políticas das diversas províncias no intuito de "extirpar os germens da discórdia provenientes dos choques de partidos que tantos males tem causado aos nossos Concidadãos das Províncias Setentrionais, quase sempre tiranizadas por Governantes idiotas dotados de uma tendência natural a infringirem a Lei". O texto ressalva que, a despeito da importância das correspondências entre as Sociedades, sua normatização iria aumentar muito o trabalho dos secretários. Portanto, a comissão deliberou que, "salvo os casos extraordinários (...) elas somente devem ter lugar pelos Correios marítimos em todos os fins dos meses, enviando-se àquelas Sociedades exemplares dos nossos Estatutos e Regimento interno, bem assim os trabalhos que existem impressos", a fim de dissipar divergências, que "nós nenhuma outra coisa queremos que não seja a Felicidade Pública, sujeita em tudo aos trâmites da carta Constitucional" ${ }^{\prime 96}$.

As lacunas nas coleções de jornais baianos também têm dificultado a identificação dos sócios da Sociedade Federal da Bahia, muitas vezes mencionados apenas pelo primeiro nome nas atas publicadas

\footnotetext{
93 Idem.

${ }_{94}$ Diário de Pernambuco, n. 269, 19 de dezembro de 1831.

95 Diário de Pernambuco, n. 306, 8 de fevereiro de 1832. O parecer foi transcrito da Gazeta da Bahia, s/d.

${ }^{96}$ Idem.
} 
nos periódicos. Aparentemente as folhas O Precursor Federal e posteriormente O Gênio Federal, este último porta-voz da associação política, imprimiam trechos das atas das sessões. Em maio de 1832, o jornal O Precursor Federal, redigido provavelmente por Luiz Gonzaga Pao Brasil ${ }^{97}$, publicou um resumo do registro da reunião, decorrida no mês anterior, da qual teriam participado 31 sócios. É preciso mencionar a proposta, aventada então, de que a Sociedade deveria se encarregar da defesa "de certo n. de presos indigentes todos os anos", o que seria deliberado pelo colegiado após a reforma dos Estatutos da agremiação ${ }^{98}$. Não se pode afirmar se tal moção foi aprovada. De qualquer forma, é de notar que, além das matérias de ordem política ou doutrinária, os associados se preocupassem com a assistência jurídica dos presos. Já no único exemplar do periódico O Gênio Federal que consta no acervo da Biblioteca Nacional, impresso em junho de 1834, há uma declaração dos princípios da Sociedade:

O Genio Federal, como órgão da Sociedade Federal da Bahia, regulará a sua marcha pelo regimento que lhe serve de Instituto, procurando quanto lhe for possível difundir por todas as classes ideias claras e exatas da Reforma Federativa e sua utilidade, os princípios da moral pública e a prática das virtudes individuais e sociais, o amor da Liberdade e da honra, a obediência às leis justas, o respeito às autoridades legítimas, e o imprescritível direito de resistir à opressão e à tirania; além disso ele será o veículo da publicação dos trabalhos da Sociedade. (...) Tais são as obrigações que nos prescrevemos, fazendo assim à face do Céu e dos homens, uma confissão franca e sincera de nossa crença política ${ }^{99}$.

No mesmo número, o jornal divulgou a ata de uma sessão extraordinária da Sociedade Federal de 22 de maio de 1834. Naquela oportunidade, foi lida uma carta de Cipriano Barata, membro da associação, comunicando a necessidade de se mudar para Pernambuco em decorrência de inúmeras perseguições. Em resposta, a Sociedade lamentou sua partida e nomeou uma comissão composta de cinco membros - Mondim, Guedes Cabral, Esteves, Santos e Firmino - para a despedida do célebre redator baiano que seguiu para Pernambuco no dia 26 de maio de 1834 . A resposta da associação a Cipriano foi assinada pelo então presidente, Jeronimo Ribeiro Neves, e pelo secretário Luís Alves Borges.

Respeitáveis e Ilustres Meus Sócios, Senhores da Patriótica Sociedade Federal. Viva a Pátria.

Em perseguição que me fazem meus inimigos (...) vejo-me pois na necessidade de me salvar, expatriando-me, antes que eles forjando novos crimes me percam, ou me assassinem, como já determinam: assim, deixo a minha terra natal, por quem tanto hei sofrido, e vou buscar guarida e salvação em Pernambuco, embarcando no primeiro paquete que passar. Portanto, eu me despeço e abraço a todos os meus Sócios, e peço as ordens da Sociedade. Daquela Província, e logo que chegue e puder mandarei pagar as pensões que devo, e houver de dever, pois sempre continuarei a ser Membro de tão digna Corporação, a qual Deus Guarde eternamente. Campinas de Brota da Bahia, aos 9 de março de 1834. Sou da Ilustre Sociedade Sócio obrigado e firme. Cipriano José Barata de Almeida

\section{Imprensa baiana e trajetórias: Domingos Guedes Cabral}

Ainda que os registros até aqui encontrados não permitam detalhar o funcionamento ou a composição da Sociedade Federal da Bahia, algumas trajetórias de notórios associados possibilitam não apenas comprovar a simpatia pelas revoltas decorridas entre 1831 e 1833, mas principalmente dimensionar a combatividade do federalismo na Bahia ${ }^{101}$.Para tal propósito, o caso de Domingos Guedes Cabral parece ser emblemático. O redator gaúcho iniciou a edição do jornal O Democrata

\footnotetext{
97 A informação é de SODRÉ, Nelson Werneck. A história da imprensa no Brasil. Rio de Janeiro: Civilização Brasileira, 1966. p. 153. 98 O Precursor Federal, n. 26, 5 de maio de 1832.

99 O Gênio Federal, n. 1, 5 de junho de 1834.

100 Idem.

${ }^{101}$ Sobre o cônego Manoel José de Freitas Baptista Mascarenhas, mais conhecido como Manoel Dendê Bus, ver MAGALHÃES, Pablo Antônio Iglésias. Deus e o Diabo na biblioteca de um cônego na Bahia: o inventário dos livros do padre Manoel Dendê Bus em 1836. Revista de História, São Paulo, n. 171, p. 245-286, jul.-dez. 2014.
} 
provavelmente em $1833^{102}$. A coleção da Biblioteca Nacional só dispõe de 15 exemplares deste periódico, todos publicados entre dezembro de 1833 e maio de 1836.

O intrépido redator de O Democrata nasceu em Pelotas, na então província de São Pedro do Sul, no dia 4 de julho de 1811. De acordo com Sacramento Blake, o pai de Domingos enviou o filho à Bahia, tendo em vista uma ocupação no comércio. No entanto, este abandonou o emprego como guardalivros para se dedicar ao estudo e à política. Inicialmente colaborou com a imprensa federalista na província e, em seguida, editou seus próprios jornais. Contudo, as agitações políticas dos primeiros anos do período regencial ganhariam espaço na vida do jovem redator, em particular os movimentos federalistas de 1831, 1832 e 1833. Em fevereiro de 1834, Guedes Cabral informa seu retorno a Salvador "livre já inteiramente da cadeia de perseguições que se nos teceu depois de 28 de Outubro de 1831 " 103. $\mathrm{Na}$ ocasião afirmava que imprimiria dois números da folha por semana. Para tanto, aumentaria o preço da subscrição trimestral do periódico para 1.400 réis e solicitava a confirmação das assinaturas.

A julgar pelos exemplares consultados, parece que tal intenção não se concretizou. Ao contrário, é possível perceber as dificuldades com as quais o redator se deparava, uma vez que, em três anos, se nota a constante mudança de tipografia, embora esse fato não fosse raro na imprensa da época. Ademais, a despeito do acervo estar incompleto, há um lapso de aproximadamente um ano em sua publicação, entre novembro de 1834 e dezembro do ano seguinte. Assim, em 7 de dezembro de 1833 o jornal era impresso na tipografia de Gueffier. Dois meses depois, se transfere para a oficina do Correio Mercantil. Em seguida, com apenas dois números publicados, o periódico recorre à conhecida casa tipográfica da Viúva Serva. Já em outubro de 1834, Guedes Cabral informa que sua folha era editada pela tipografia Patriótica-Federal. Todavia, esta parece não ter sobrevivido por muito tempo, de vez que em dezembro de 1835 é substituída pela tipografia Costa e Sousa. Finalmente, após cinco meses, o último exemplar da coleção foi impresso pela oficina de J. A. de Andrade Silva e Freitas.

O redator gaúcho analisou no Democrata vários assuntos que abrangiam a imigração de colonos europeus e o fim do tráfico de escravos, os conflitos na região do Prata, a Revolução Francesa e seus desdobramentos, assim como a Cabanagem no Pará e a Revolução Farroupilha em sua província natal. Em dezembro de 1835, Guedes Cabral decide divulgar na íntegra o projeto, apresentado em maio pelo deputado baiano Antônio Ferreira França à Câmara dos Deputados, que pleiteava a instauração imediata do governo eletivo e temporário no Brasil:

Vamos ocupar o nosso número de hoje com uma matéria sobremaneira importante e da maior transcendência para todos os Brasileiros que, estranhos ao desinteresse, à ambição e à venalidade, sentem arder no peito a chama do verdadeiro patriotismo [ileg.] vamos chamar a atenção de todos (...) para o Projeto de Reforma Constitucional, apresentado por o Nobre Deputado o Sr. Dr. Antonio Ferreira França, em a sessão de 16 de Maio do ano corrente

A Assembleia Geral Legislativa decreta

1- O Governo do Brasil cessará de ser patrimônio de uma família.

2- O atual Imperador, e suas Augustas Irmãs, cederão de seu privilégio e receberão, por uma vez, um subsídio para completarem sua educação e principiarem seu estabelecimento.

3- A Nação será governada por um chefe eleito de dous em dous anos no dia 7 de Setembro, a maioria de votos dos Cidadãos Eleitores do Brasil ${ }^{104}$.

Às reformas políticas correspondiam, segundo a orientação do periódico baiano, as mudanças que deveriam ser implementadas na sociedade, em especial a emancipação dos escravos e sua correlata substituição pelo trabalho livre. Desse modo, inscreve em seu jornal um longo comentário a propósito

\footnotetext{
${ }_{102}$ De acordo com BLAKE, Augusto V. A. Sacramento. Dicionário...Op. Cit., vol. II, p. 205, o jornal O Democrata circulou entre 1836 e 1842. Entretanto, o acervo da Biblioteca Nacional possui exemplares publicados entre 1833 e 1836.

103 O Democrata, n. 29, 7 de fevereiro de 1834.

${ }^{104}$ O Democrata, n. 73, 1 de dezembro de 1835. Apesar da euforia do redator, o projeto sequer fora votado na Câmara. A proposição foi preliminarmente apreciada e, após rápida discussão, decidiu-se por uma maioria de 44 deputados contra 33 que a proposta de reforma não seria formalmente apresentada.
} 
da obra do conselheiro Miguel Calmon du Pin e Almeida, Memória sobre o estabelecimento de uma companhia de colonisação nesta provincia, publicada em 1835. Domingos Guedes Cabral pretendia rejeitar a sugestão, amplamente defendida à época, de se estimular a entrada de colonos europeus no Brasil, por meio da criação de companhias que financiariam a viagem e o estabelecimento dos trabalhadores. Ponderava o redator que a importação de tais colonos constituía uma injustiça com os brasileiros, além de não suprir a demanda de braços para a lavoura ${ }^{105}$. Argumentava que deveriam ser criadas "Sociedades ou Companhias protetoras da emancipação dos escravos" que priorizassem esses "desventurados nascidos em a nossa terra que são nossos patrícios e irmãos e que todavia, com horror da humanidade e opróbrio do nome brasileiro, gemem debaixo do açoite da bárbara escravidão". Guedes Cabral contestava a "contradição vergonhosa" de se proibir a entrada de africanos e perdurar o comércio de escravos, "levando todos os dias ao mercado e aos suplícios mais infames aqueles a quem Deus criou com todos os direitos do homem"106. Para reforçar sua proposição, recorre ao livro de Ignacio Accioly de Cerqueira e Silva, Corographia paraense, ou Descripção physica, historica e politica da provincia do Grão-Pará, publicada pela tipografia do Diário em 1833, que censurava a importação de trabalhadores europeus ${ }^{107}$. A violenta oposição ao governo regencial, notadamente ao criticar o envio de tropas contra a Cabanagem no Pará, muito provavelmente explica sua intenção de sair de Salvador, manifesta na edição de 16 de abril de 1836. De qualquer forma, não há mais notícias do redator até a década de 1840, quando Guedes Cabral inicia a publicação do jornal O Guaycuru, provavelmente o mais longo periódico republicano a circular no Império do Brasil ${ }^{108}$.

Pelo que foi exposto, observamos que o tempo das regências significou efetivamente um marco na história do Brasil imperial. Qualificado "como um grande laboratório de formulações e de práticas políticas e sociais" por Marco Morel ${ }^{109}$, os primeiros anos da década de 1830 favoreceram a expressão de diversas correntes de opinião que ganharam voz nas ruas, nas associações políticas e sobretudo na imprensa. Assim, a despeito da dispersão das informações, este artigo buscou recuperar alguns temas conhecidos da historiografia, como as sublevações no início do período regencial em Pernambuco e na Bahia, além de outros bem menos pesquisados pelos historiadores, como a criação das sociedades políticas, à luz quase que exclusivamente das narrativas dos periódicos de ambas as províncias. Por fim, o texto também procurou demonstrar a articulação entre a atuação das sociedades políticas federais e as revoltas federalistas, seja pela mediação nas negociações com o governo provincial, seja por meio da participação direta de seus associados.

\section{Referências bibliográficas}

\section{Periódicos}

Bandeira de Retalhos, 1832.

Bússola da Liberdade, 1831, 1832.

O Bahiano, 1831.

O Carapuceiro, 1832.

O Democrata, 1833-1836.

Diário da Bahia, 1833.

Diáario de Pernambuco, 1831, 1832.

Escudo da Constituição Brasileira, 1831.

Espelho das Brazileiras, 1832.

O Federalista, 1831-1833.

\footnotetext{
105 O Democrata, n. 74,22 de dezembro de 1835.

106 Idem.

107 Curiosamente, em 1847, Domingos Cabral viria a editar pela própria tipografia, Guaycuru, outra obra de Cerqueira e Silva, a Informação ou Descrição Topográfica e política do rio São Francisco, escrita em virtude de ordens imperiais e apresentada ao governo provincial da Bahia

108 O Guaycuru circulou na Bahia entre 1843 e 1860.

109 MOREL, Marco. O período das regências... Op. Cit., p. 9. 
Gazeta da Bahia, 1831.

O Gênio Federal, 1834.

Nova Luz Brasileira, 1831.

O Precursor Federal, 1832.

\section{Panfletos e manuscritos}

Acontecimentos em Pernambuco para inaugurar uma republica, 1829. Divisão de manuscritos da Biblioteca Nacional.

Coleção de Leis e Decisões do Império do Brasil, 1825-1832. Rio de Janeiro: Typographia Nacional, 1876.

Correspondência do presidente da província da Bahia (1831-1832). Arquivo Nacional. Ofícios do Governo da Bahia.

Devassa instaurada pelo crime de distribuição de pasquins sediciosos (...). Recife, Instituto Arqueológico Histórico e Geográfico Pernambucano, 1829.

Hum Verdadeiro Constitucional (pseudônimo), Defesa ou Fiel e verdadeira exposição dos acontecimentos que tiverão lugar no Rio de Janeiro, por occasião da chegada de SS. MM. II nas noites de 11 a 15 de março, que ao respeitável Corpo do Commercio, offerece um Verdadeiro Constitucional. Rio de Janeiro: Typographia do Diário, 1831.

Ofício de Gustavo Adolfo de Aguilar sobre a rebelião republicana ocorrida em Pernambuco. Recife, 30 de março de 1829. Divisão de manuscritos da Biblioteca Nacional.

Relação dos Reus pronunciados na Devassa dos Pasquins que se acham presos. Divisão de Manuscritos da Biblioteca Nacional.

\section{Livros, teses e artigos}

ANDRADE, Manuel Correia de. Movimentos nativistas em Pernambuco: setembrizada e novembrada. Recife: Universidade Federal de Pernambuco, 1971.

ARAS, Lina Maria Brandão de. A santa federação imperial. Tese (Doutorado), Universidade de São Paulo, São Paulo, 1995.

Atas do Conselho de Estado. Brasília: Gráfica do Senado Federal, 1973.

AZEVEDO, Manuel Duarte Moreira de. Sociedades fundadas no Brasyl desde os tempos coloniais até o começo do actual Reinado. Revista Trimensal do Instituto Histórico, Geographico e Ethnographico do Brasil. Rio de Janeiro: Typ. de Laemmert, 1885. tomo XLVIII, parte 2.

BASILE, Marcello. Inventário analítico da imprensa periódica do Rio de Janeiro na Regência: perfil dos jornais e dados estatísticos. In: CARVALHO, José Murilo de; NEVES, Lúcia M. Bastos P. das (org.). Dimensões e fronteiras do Estado brasileiro nos Oitocentos. Rio de Janeiro: Eduerj, 2014.

. O Império em construção: projetos de Brasil e ação política na corte regencial. Tese (Doutorado), UFRJ, Rio de Janeiro, 2004.

BASILE, Marcelo O. N. de Campos. O laboratório da nação: a era regencial (1831-1840). In: GRINBERG, Keila; SALLES, Ricardo (org.). O Brasil imperial. Rio de Janeiro: Civilização Brasileira, 2009.

BLAKE, Augusto V. A. Sacramento. Diccionario bibliográphico brazileiro. Rio de Janeiro: Imprensa Nacional, 1900.

BUENO, Jose Antônio Pimenta. Direito público brasileiro e análise da Constituição do Império. Brasília: Senado Federal, 1978.

CARVALHO, José Murilo de. Cidadania: tipos e percursos. Estudos Históricos, Fundação Getúlio Vargas, n. 18, 1996.

CARVALHO, Marcus J. M. de. Aí vem o capitão-mor: as eleições de 1828-30 e a questão do poder local no Brasil imperial. Tempo, Universidade Federal Fluminense, Departamento de História, vol. 7, n. 13, 2002.

COSTA, Francisco Augusto Pereira da. Anais pernambucanos. Recife: Arquivo Público Estadual, 1965.

COSTA, Francisco Augusto Pereira da. Diccionário biográphico depernambucanos céelebres. Recife: Typographia Universal, 1882.

FELDMAN, Ariel. Espaço público e formação do Estado nacional brasileiro: a atuação política do padre 
Carapuceiro (1822 a 1852). Tese (Doutorado), Universidade de São Paulo, São Paulo, 2013.

Guerra aos extremos: polarização política em Pernambuco e a defesa do princípio de soberania nacional (1829-1831). Almanack, Guarulhos, n. 7, p. 39-58, junho de 2014.

FONSECA, Silvia C. P. de Brito. A ideia de República no Império do Brasil: Rio de Janeiro e Pernambuco (18241834). Jundiaí: Paco Editorial, 2016.

Em Pernambuco os que oram também lutam: a imprensa abatinada e seus embates conceituais (1829-1831). Pós-História, Assis, n. 13/14, 2005/2006.

A República em negativo: o sistema conceitual do padre Carapuceiro. Almanack, Guarulhos, n. 3, p. 99-115, junho de 2012.

FÜRSTENAU ,Vera. Jornais e leitores: uma polêmica apaixonada na cidade do Rio de Janeiro (1831-1837). Dissertação (Mestrado), UFRJ, Rio de Janeiro, 1994.

GUIMARÃES, Lúcia Maria Paschoal. Em nome da ordem e da moderação: a trajetória da Sociedade Defensora da Liberdade e da Independência Nacional do Rio de Janeiro (1831-1835). Dissertação (Mestrado), UFRJ, Rio de Janeiro, 1990.

HABERMAS, Jürgen. Mudança estrutural na esfera pública. Rio de Janeiro: Tempo Brasileiro, 1984.

KOSELLECK, Reinhart. Crítica e crise: uma contribuição à patogênese do mundo burguês. Rio de Janeiro: Eduerj; Contraponto, 1999.

KRAAY, Hendrik. Daniel Gomes de Freitas: um oficial rebelde do exército imperial brasileiro. Politeia: História e Sociedade, revista da Universidade Estadual do Sudoeste da Bahia, Vitória da Conquista, vol. 4, n. 1, p. 135-158.

LINDOSO, Dirceu. A utopia armada. São Paulo: Paz e Terra, 1982.

LIMA, Ivana Stolze. Cores, marcas e falas: sentidos da mestiçagem no império do Brasil. Rio de Janeiro: Arquivo Nacional, 2003.

LYRA, Maria de Lourdes Viana. O império em construção: Primeiro Reinado e regências. São Paulo: Atual, 2000 .

LOPES, José Reinaldo de Lima. Iluminismo e jusnaturalismo no ideário dos juristas da primeira metade do século XIX. In: JANCSÓ, István. Brasil: formação do Estado e da nação. São Paulo: Hucitec; Ed. Unijuí; Fapesp, 2003.

MAGALHÃES, Pablo Antônio Iglésias. Deus e o Diabo na biblioteca de um cônego na Bahia: o inventário dos livros do padre Manoel Dendê Bus em 1836. Revista de História, São Paulo, n. 171, p. 245-286, jul.-dez. 2014.

MATTOS, Ilmar Rohloff de. Construtores e herdeiros. A trama dos interesses na construção da unidade política. In: JANCSÓ, István (org.). Independência: história e historiografia. São Paulo: Hucitec: Fapesp, 2005 .

\section{O tempo saquarema. São Paulo: Hucitec; Brasília: INL, 1987.}

MOREL, Marco. As transformações dos espaços públicos. Imprensa, atores políticos e sociabilidades na cidade imperial (1820-1840). São Paulo: Hucitec, 2005.

. O período das regências (1831-1840). Rio de Janeiro: Jorge Zahar, 2003.

. Restaurar, fracionar e regenerar a nação: o Partido Caramuru nos anos 1830. In: JANCSÓ, István (org.). Brasil: formação do Estado e da nação. São Paulo: Hucitec; Ed. Unijuí; Fapesp, 2003.

NASCIMENTO, Luiz do. História da imprensa de Pernambuco (1821-1954). Recife: UFPE, 1969.

QUINTAS, Amaro. O Nordeste e a Bahia (1825-1850). In: CAMPOS, Pedro Moacyr; HOLLANDA, Sérgio Buarque de (org.). História geral da civilização brasileira. São Paulo: Difel, 1978. tomo II, $2^{\circ}$ vol.

REBOUÇAS, Antônio Pereira. Recordações patrióticas (1821-1838). Rio de Janeiro: Typ. G. Leuzinger \& Filhos, 1879.

RIBEIRO, Gladys Sabina. A liberdade em construção. Rio de Janeiro: Relume Dumará; Faperj, 2002.

SILVA, Antônio de Moraes. Diccionário da língua portuguesa... Lisboa: Typographia de Antônio Jose da Rocha, 1858.

SILVA, Daniel A. da. A duras e pesadas penas: imprensa, identidade e nacionalidade no Brasil imperial. Topoi, Rio de Janeiro, vol. 10, n. 19, p. 55-69, jul.-dez. 2009.

. Na trilha das garrafadas: a abdicação de D. Pedro I e a afirmação da identidade nacional brasileira na Bahia. Análise Social, Lisboa, n. 203, p. 268-297, 2012. 
SILVA, Wlamir Jose da. Liberais e povo: a construção da hegemonia liberal moderada na província das Minas Gerais (1830-1834). São Paulo: Hucitec, 2009.

SODRÉ, Nelson Werneck. A história da imprensa no Brasil. Rio de Janeiro: Civilização Brasileira, 1966.

SOUSA, Octavio Tarquínio de. História dos fundadores do Império do Brasil. Rio de Janeiro: José Olympio Editora, 1957.

SOUZA, Iara Lis Franco Schiavinatto Carvalho. Pátria coroada: o Brasil como corpo político autônomo (17801831). São Paulo: Fundação Editora da Unesp, 1999.

VIANA FILHO, Luiz. A Sabinada (A República bahiana de 1837). Rio de Janeiro: Livraria José Olympio Editora, 1938.

WERNET, Augustin. As sociedades políticas na província de São Paulo na primeira metade do período regencial. Tese (Doutorado), USP, São Paulo, 1975. . Sociedades políticas (1831-1832). São Paulo: Cultrix, 1978.

Recebido em: 01/04/2018 - Aprovado em: 01/10/2018 